\title{
فاعلية استخدام خبرات الطهي في تنمية مفهوم القياس لدى طفل الروضة
}

$$
\text { إعراد }
$$

الباحثة / سارة الأحمدي محمد أحمد سلامة

$$
\text { معلم رياض أطفال بالتربية والتطليم }
$$

$$
\text { إبراف }
$$

$$
\begin{aligned}
& \text { د / عبير عبــده الشـرقاوي } \\
& \text { مدرس علم النفس الطفل } \\
& \text { كليت الطفولت المبكرة } \\
& \text { جامعت المنصورة }
\end{aligned}
$$$$
\text { أ.د / أمل محمد القداح }
$$$$
\text { أستاذ مناهـج وبرامـج الطفل }
$$$$
\text { وكيل الدراسات العليا والبحوث }
$$$$
\text { عضو لجنت قطاع دراسات الطفولت }
$$$$
\text { جامعتشالمنصورة }
$$

$$
\begin{aligned}
& \text { المجلت العلميتّ لكليت التربيت للطفولت المبكرة ـ جامعت المنصورة }
\end{aligned}
$$

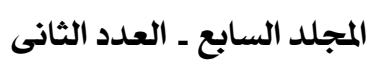

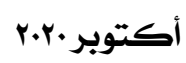




\section{فاعلية استخدام خبرات الطهي في تنمية مفهوم \\ القياس لدى طفل الروضة حئة}

* سارة الأحمدي محممد أحمد سلامتم

\section{مقدمة}

تُعد مرحلة الطفولة المبكرة من أخصب و أهم مر احل العمــر فــي حيــاة

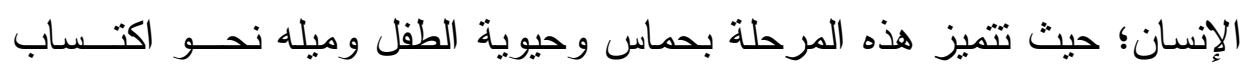

المهار ات المعارف، فكلما كانت بيئة الطفل غنية بــالمثير ات و اللعــب و المتعــة

و التسلية كلما اكتسب الطفل مهار ات ومعارف ومفاهيم في بناء معرفته .

كما أن الحديث عن الطفولة هو النظرة إلى المستقبل بكل ما تعنيه الكلمـــة من معان ولذلك هى تُعد من الفئات التي يُعتتى بها كثير اً فلا شك أن الأطفال هم

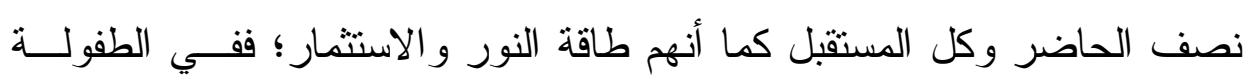
استثمار للمستقبل كله لتحقيق أمن وحضارة وثقافة وطن بأكمله ففي هذه المرحلة يتم وضع الركائز فيها لثخصية الط+فل التي تتبلور وتظهر في حياة الفرد . و لا شك أن التعلُّم لدى الأطفال في مرحلة الروضة يعتمد بشكل كبير الى

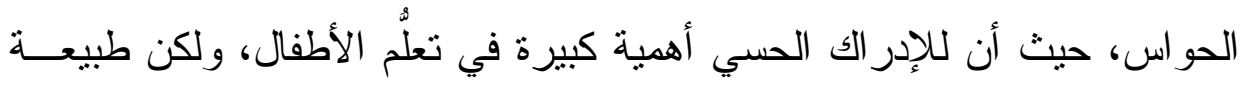

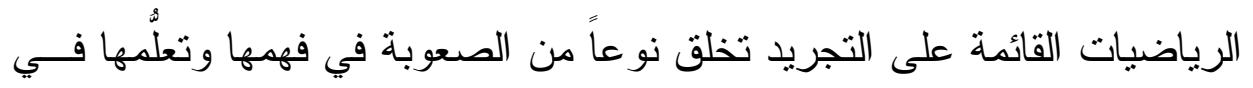
هذه المرحلة، ويجد الأطفال صعوبة في فهم العلاقـات المجــردة مــن أرقــام وتعريفات وترجمتها بالثكل الصحيح؛ لذا فإن تعلُّم الرياضيات يحتاج إلى تدعيم لتقليل صعوبة تعلُّها وفهمها لديهم، وتُعد المفاهيم الرياضية من المفاهيم المهمـــة

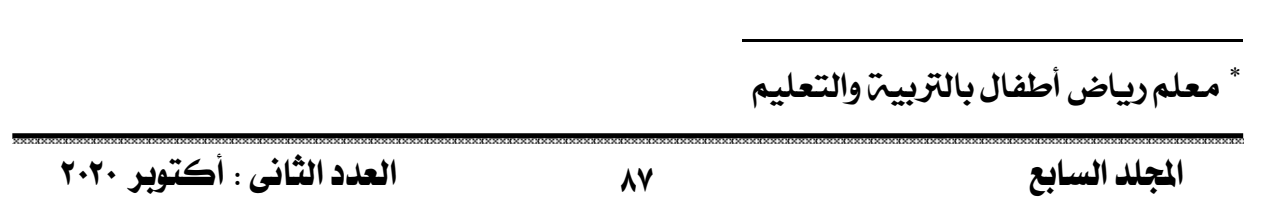


في تعلُّم طفل ما قبل المدرسة؛ إذ تُعد أساساً قويـــاً لــتعلمّم العلــوم و المعــارف

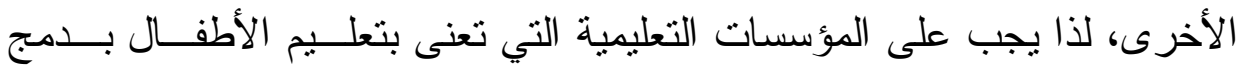
التقنية في عملية تعلمهم بنواحي مختلفة من خلال المو اقف التعليمية المباشرة، أو أو

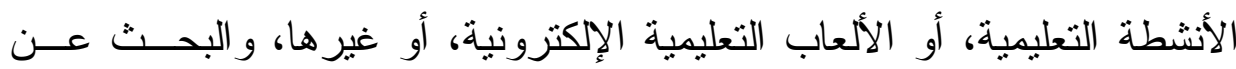
أفضل الممارسات و الأساليب التربوية التي تسهم مـسـاهمة فعّالـــة فـــي تتميــة مهار اتهم ومو اكبة الثورة الرقمية.

(Booth \& Siegle, و أكدت بعض الدر اسات كدر اسة بـوث وســيجل (2008 أنه يصعب على الأطفال التمكن من حقائق الأعداد دون فهـم علاقــات الأعداد على خط الأعداد، و عليه فإن القصور في أي جزء من أجز اء المعرفــة العددية المبكرة بما في ذلك العدَ و الأعداد، يتسبب في بطء في المر احل الدراسية اللاحقة إذا لم يتم تداركه بشكل مناسب من خلا البحث و الاستقصاء و الاهتمــام الكبير بالطرق الملائكة و الحديثة لتعليم الأطفال. كما توصنّل جـوردان وليفــاين (Jordan \& Levine, 2009) مهار ات القياس لديهم قصور في المعرفة الرمزية بالأعداد أيضناً، والتـي تتـأثز إلى حد كبير بتعلٌم مفاهيم الرياضيات في سن مبكرة. ولهذا فإن تطوير عملية تعليم الرياضيات وتعلُّهها، يستوجب الابتعاد عــن الإطار التقليدي في تدريسها، و البحث عن مداخل حديثة تتماشــى مــع طبيعــة تدريسها في القرن الحادي و العشرين، وتبنِّي الاستر اتيجيات التفاعليــة النــشطة التي تركز على إيجابية المتعلم وتتمية قدر اته العقلية، وجعله نشطاً؛ ليتمكن مــن

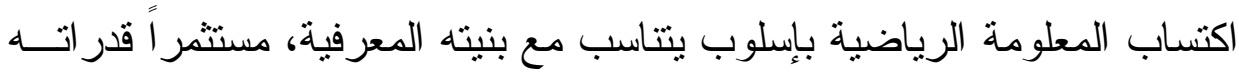




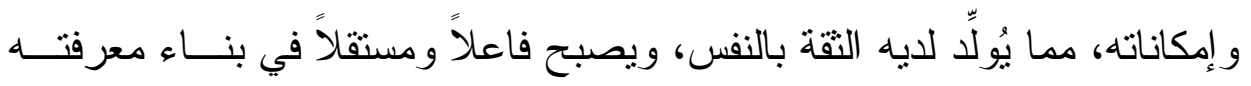

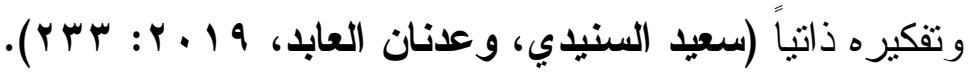

و انطلاقاً من تلك الحقائق كان لابد من الاستمر ار في تطوير تلك القدرات

وتوجيهها بما يحقق الأهداف التربوية المطلوبة، ويضمن النمو السليم و التــوازن للطفل، وذلك ليس فقط من خلا إعداد المناهج المناسبة لطفل الروضة، و إنمـــا

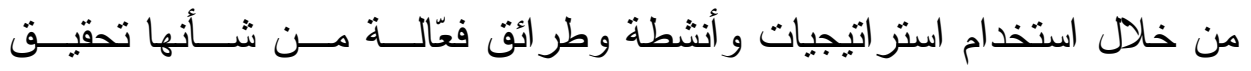
الأهداف المرجوة، ومن أفضل الطرائق لإكساب المهار ات العلمية هو أن يتعلمها

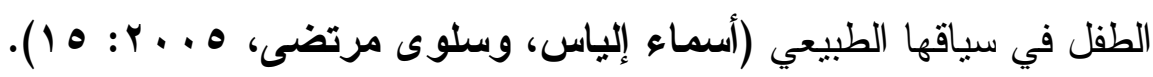
ومن أهم الطرق الجاذبة لطفل الروضة التي يمكـنـ اســتخدامها لتتميــة بعض المفاهيم الرياضية لديه هو استخدام خبرات الطهي، حيث يمكن توظيفهــا لكونها أحد أهم الوسائل المثيرة و الفعالة التي تمد الطفل بالمعلومات و المهــارت

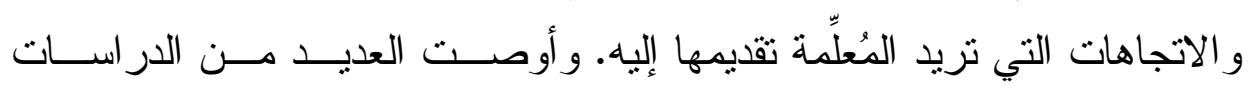
بضرورة تبني استخدام الأركان التعليمية ومن بينها ركن الاسرة فـــي عمليــة وليهة تعليم الأطفال؛ مما يساعد على تضافر الجهود لتحقيق التمبز في العناية بتنميـــة وتطوير المفاهيم الرياضية لدى الطفل، وجعلها الأســاس للمر احــل التعليميـــة اللاحقة، وخاصة في مجال الرياضيات لاكتساب المفاهيم الرياضية في مر احـل

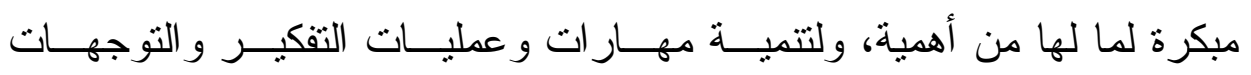

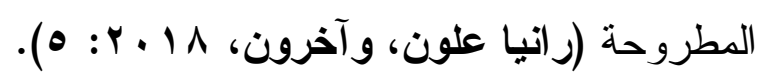

كما أن خبر ات الطهي تعتبر من أهم الخبرات التربوية الفعالة التــي لهـــا

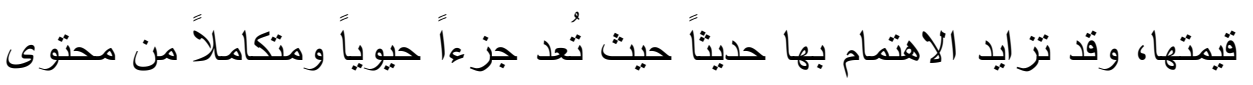
بر امج الروضة، كما تؤكد أحدث الإتجاهات الحديثة في مجال تعليم وتعلم الطفل 
على ضرورة الاهنمام بها لأنها تتيح للأطفال كيف يتعلمو المفــاهيم المجــردة بصورة أدائية، ومن أمثلة تلك المفاهيم هو مفهوم القياس .

كما أن مفهوم القياس من المفاهيم الأساسية التي يجــب تقـــيمها لطفـلـل الروضة لما لها من تأثير ؛ حيث تساعد على التفكير السليم عند الأطفــال ونمـــو المفاهيم المجردة عن طريق تزويدهم بالمعارف و المهار ات الرياضية اللازمسـة؛ بالإضافة لكونها من المفاهيم المهمة و الأساسية في تعلم الأطفال؛ حيــــ يُشـشكل بناء المفاهيم ومنها الرياضية حجر الأساس لانطلاق الأطفال في تعَلم الكثير من

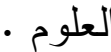

ومما لاشك فيه أن التعلم في مرحلة الروضة بصفة عامة بعتمد وبـشكل

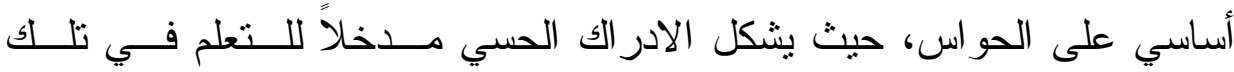
المرحلة، و الرياضيات بطبيعتها المجردة تُشكل قدر اً من الصعوبة على الأطفــال في تلكك المرحلة العمرية؛ حيث يجد الطفل نفسه أمــام سلاســل مــن الأرقــام و الأعداد و القياسات التي لا يستطيع فهمها أو ترجمتها على نحو ذو معنى له . وترجع أهمية تعلم مفهوم القياس من خــلال خبــرات الطهـــي لطفـلـ الروضة؛ في كونها تتيح للطفل القيام بمهام و أعمال مستقبلية في ضوء الخبر ات التي يمر بها؛ حيث يساعد التدريب على تللك المفاهيم على أن يكتهـب الطفـلـ المفاهيم الرياضية المرنبطة به كالعَد و التصنيف و الترنيب وغيرها من المفاهيم . ويعد مفهوم القياس العنصر الأهم من عناصر البنية المعرفية الرياضية لدى

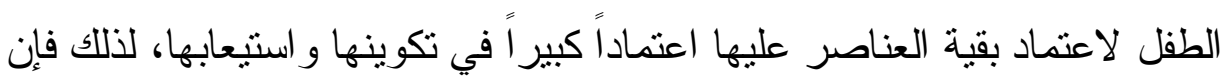
لتعلم المفاهيم أهمية و اسعة في حياة الطفل؛ حيث إنها تـسـاعده علــى التعــرف 
و التمييز و التفسير للظو اهر و المو اقف التي تحيط به وتقلل من تعقيدها ـ (بطــرس

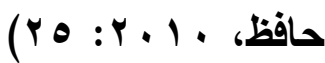

لذا ينبغي أن يتجه التعليم بالروضة في معظمه نحو تعلم المفــاهيم لأنهــا

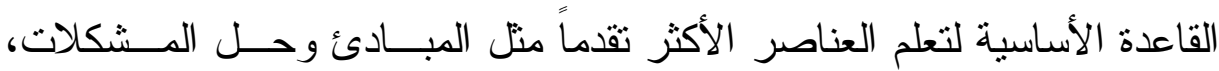

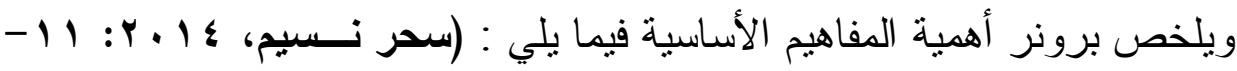

1. تجعل المادة الدر اسية أكثر سهولة لتعلمهاو واستيعابها.

r. إن فهم المفاهيم الأساسية هو الأسلوب الوحيد لزيادة فاعلية التعلم و انتقال

$$
\text { أثزره للمو اقف و الظروف الجديدة . }
$$

r. تسهم الدفاهيم في تضييق الفجوة بين المعرفة السابقة للمتعلم و اللاحقة. وتُعد مُعلِّة رياض الأطفال المقوم الرئيس لنجاح العملية التربوية لأطفال

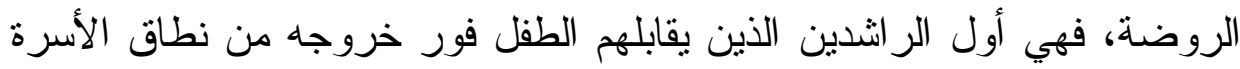

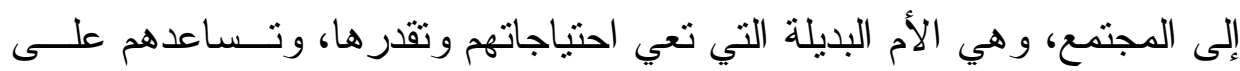

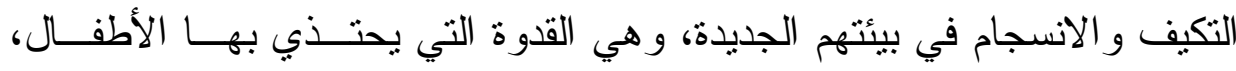

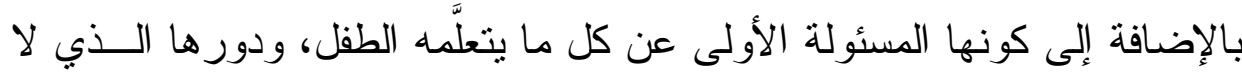

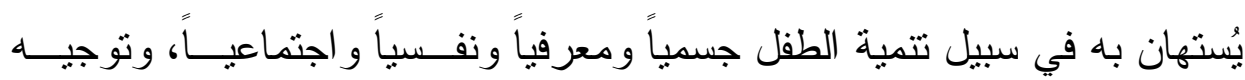
نشاطه الذاتي نحو الارتقاء بنموه وميوله.

و هي المنوط بها إعداد أنثطة الطهي المناسبة، لإكساب أطفال الروضـــة

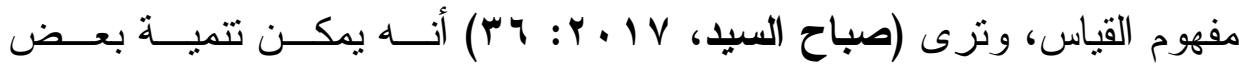

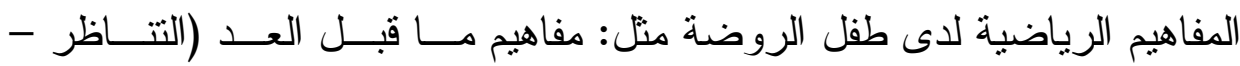


التسلسل - التصنيف - التكافؤ)، ومفاهيم العد،و المفاهيم الهندية (دائرة - مثلث - مربع - مستطيل)، ومفاهيم النرتيب. فأنشطة الطهي بجانب أنها تناعد الطفل

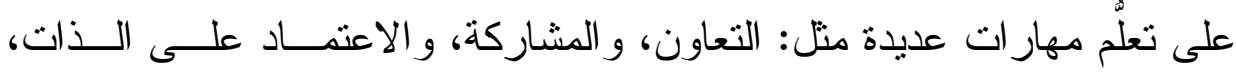

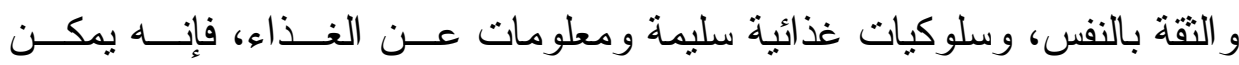
لأنشطة الطهي أن تُكسب الطفل مفهوم القياس.

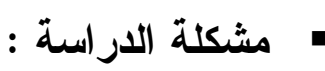

\section{تم التوصل لمشكلة البحث من خلال ما يلي :}

1) ملاحظة الأطفال بالروضات حيث لوحظ نقص و عيهم و امتلاكهم لدفهـوم القياس - (القاس

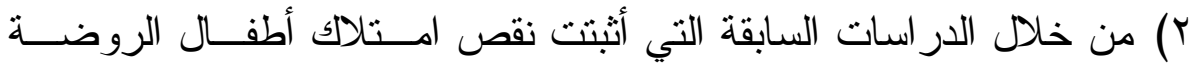

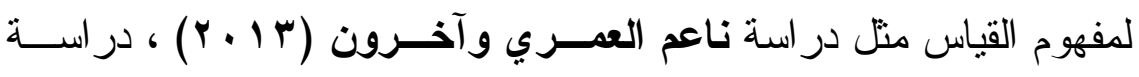

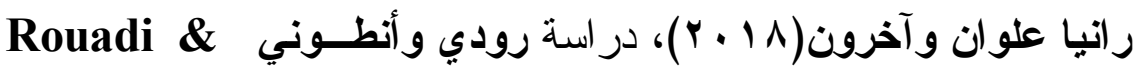

(Anouti, 2020)

r) من خلال نتائج الدراسة الاستطلاعية التي قامت بها دراسة أمل القـــاح

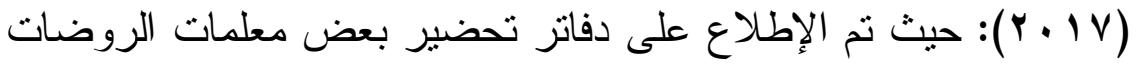

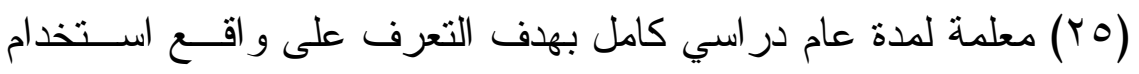

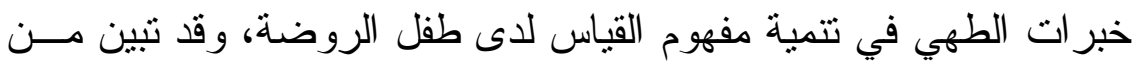

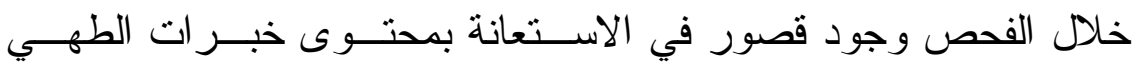

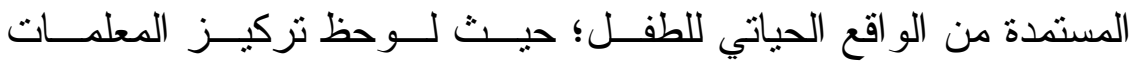

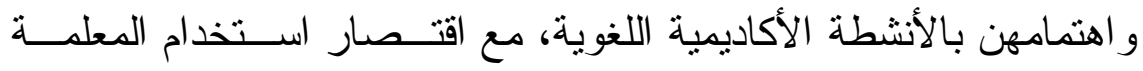

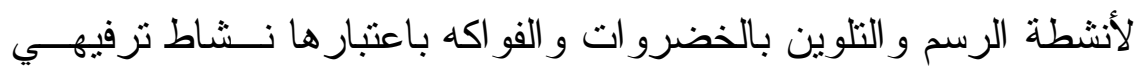


ولم تتيح الفرصة للممارسة العملية لخبر ات الطهي من قبل الطفل بغرض

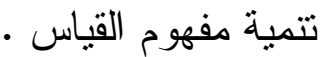

ومما سبق يتضح وجود قصور في تنمية هذه المفاهيم بالواقع الميداني

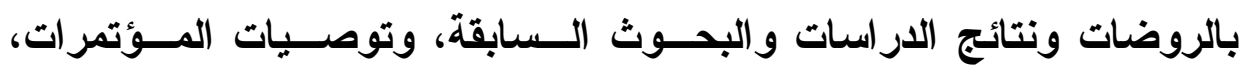
والمقترحات التي أوصت بها الدراسات السابقة رأت الباحثة القيام بهذا البحث

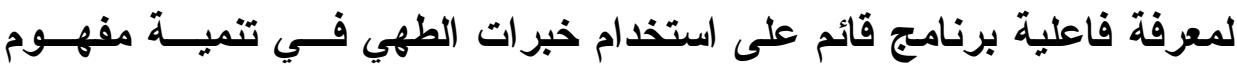

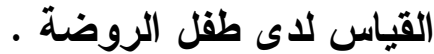

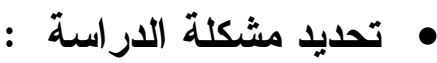

تحددت مشكلة الدر اسة في ضعف امتلالك أطفال الروضة لـفهوم القيــس

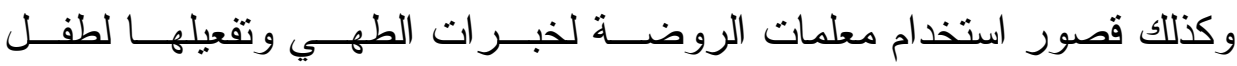
الروضة، وبالتالي يمكن تحديد مشكلة الدر اسة في التساؤل الرئيس التالي " مـــ

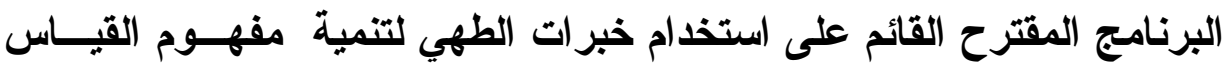

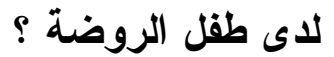
ويتفرع من التساؤل الرئيس مجموعة من التساؤلات الفرعية الآتية :

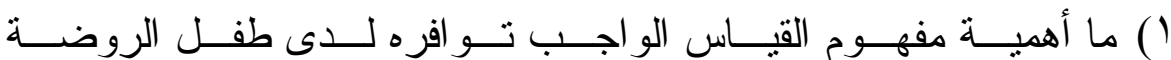

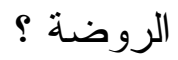

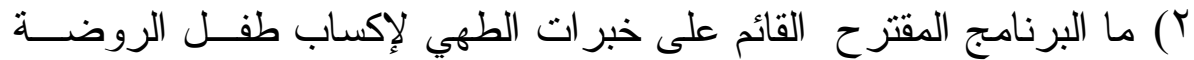

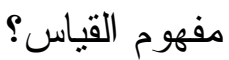

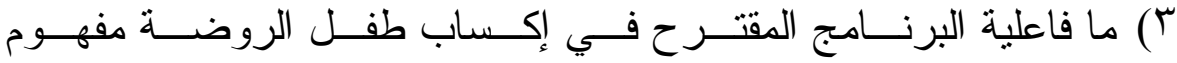

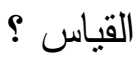




$$
\text { أهداف الار اسة : أن }
$$

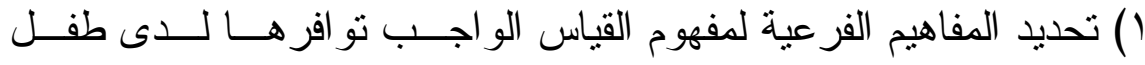

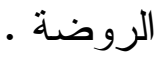

r) إعداد برنامج مقتر ح قائم على استخدام خبر ات الطهـــي لتتميــة مفهـوم

$$
\text { القياس لدى طفل الروضة. }
$$

r) تحديد فاعلية البرنامج المقترح ح القائم على استخدام خبر ات الطهي لنتميــة

$$
\text { مفهوم القياس لدى طفل الروضة . }
$$

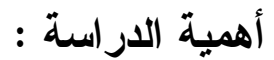

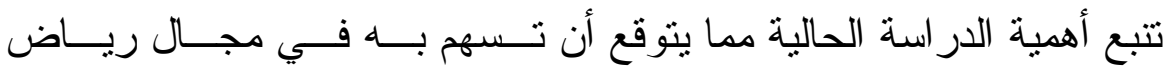

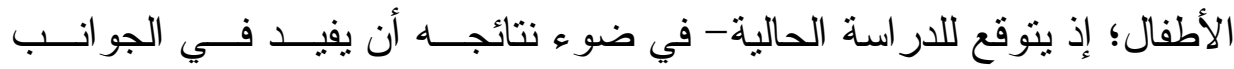

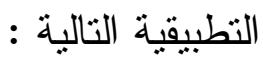

1. تقديم قائمة بالمفاهيم الفرعية لمفهوم القياس التي يمكن تتميتها من خــلال

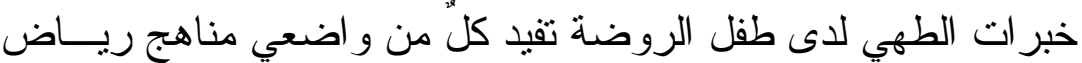

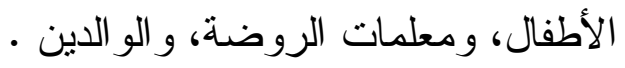

r. الاستفادة من نتائج الدر اسة لإعداد بر امج تربويــة لمرحلــة الروضـــة

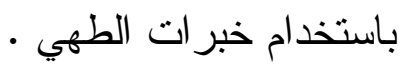

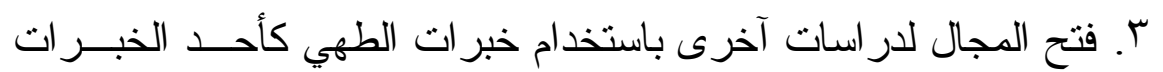

الحياتية التي تيسر اكتساب وتتمية المفاهيم لدى الطفل بـصورة واقعيــة

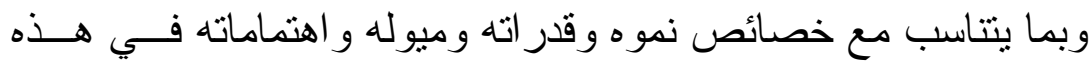

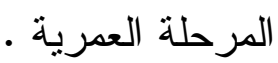

العدد الثانى : أكتوبر •r.r 
تعُرف إجر ائياً بأنها : " مجمو عة من الخبر ات التربوية المرتبطة بــالطبخ،

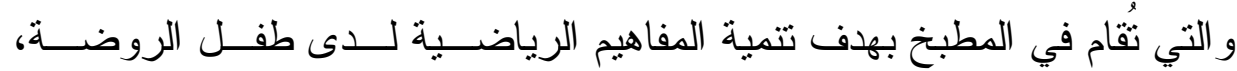

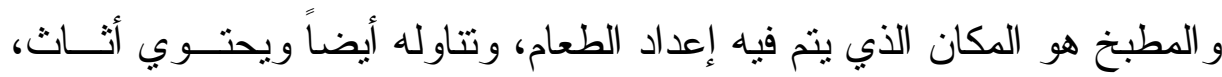
و أجهزة، وأدو ات خاصة بالطهي، وخامات، ومو اد طهي مخزنة فيه ". (r

يُُرف إجر ائياً بأنه : " قدرة الطفل على اســـخدام تقــير ات أو مقــييس

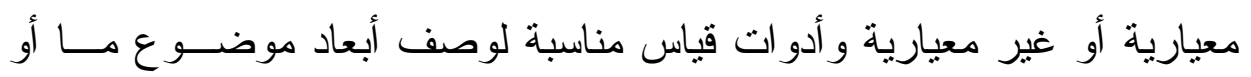
حدث في صورة كمية، ويُقاس بالدرجة التي يحصل عليها الطفل فــي الاختبــار

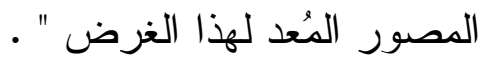

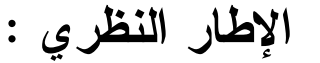

يتميز العصر الحالي بالتطور والتغير السريع المتلاحق في كافة المجالات العلمية و العملية، ففي الوقت الذي كانت تتسم فيه العمليــة التربويـــة بالبـسـاطة، وتقتصر على تعليم مهار ات القراءة والكتابة، أصبحت الآن عملية معقدة تتضمن لتصن

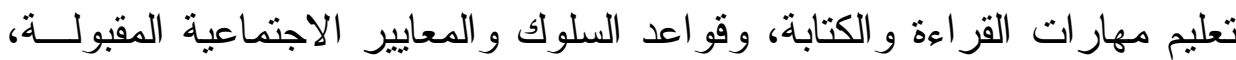

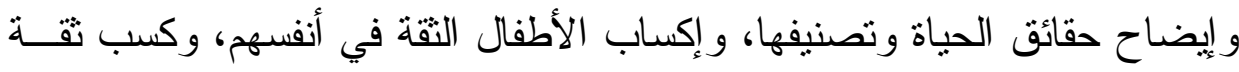

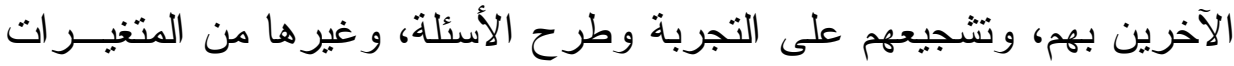

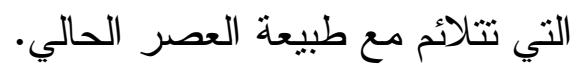




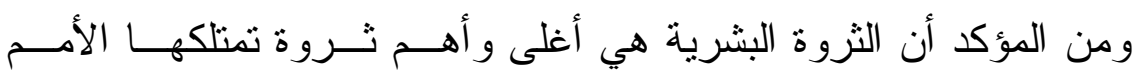

المتقدمة و النامية، وتُدرك الدول المتحضرة أهمية رعاية الطفولة و العنايـــة بهــــا،

لذا خصصت لها أكبر قدر من اهتمامها للارجة التي أصبح معيـار الحــضارة و التقدم بين الأمم هو مقدار اهتمام كل أمة بأطفالها.

وتُعد خبر ات الطهي من أهم المداخل التي يمكن استخدامها لتتمية الــوعي

الغذائي و الصحي و إكساب طفل الروضة بعض المفاهيم الرياضية، حيث يمكـنـ

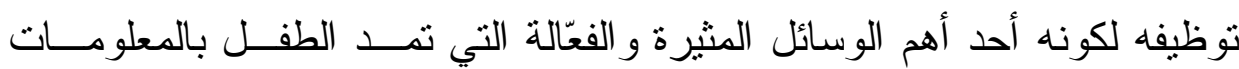
و المهار ات و الإتجاهات التي نزيد المُعلِّة تقديمها إليه.

وتم تناول الإطار النظري من خلال محورين يرتبط كل منهما ارتباطــاً وثيةـــاً

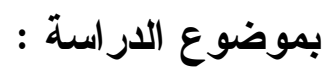

• المحور الأول : خبرات الطهي، ويتضمن تعلَم طفل الروضـــة مــن خــله خبر ات الطهي، أهمية خبرات الطهي، دور المعلمة في الإعــداد لخبــرات - الطهي

ثـ المحور الثاني : مفهوم القياس، ويتضمن تعريف مفهوم القياس، المفــاهيم الفرعية لمفهوم القياس، دور المعلمة في تتمية مفهوم القيــاس مــن خــله خبر ات الطهي • * المحور الأول : خبرات الطهي تعتبر مرحلة الروضة أهمّ مرحلة لأنّها أولى خطو ات تعليم الطفل، فهـي

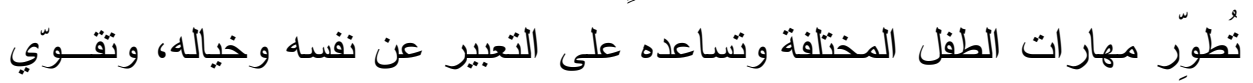

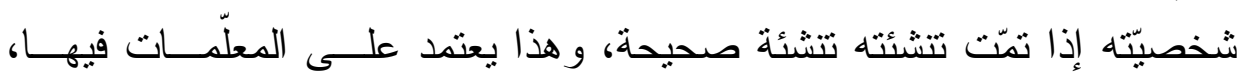




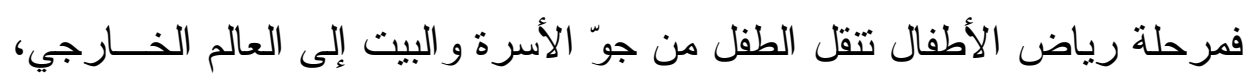

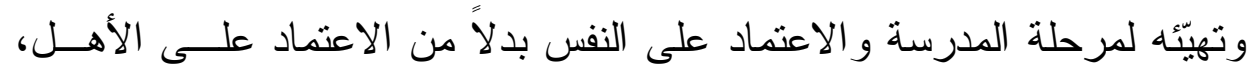

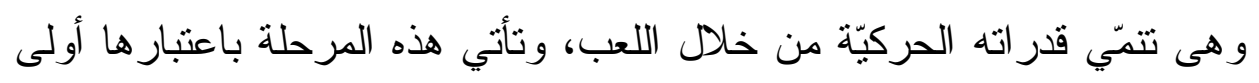

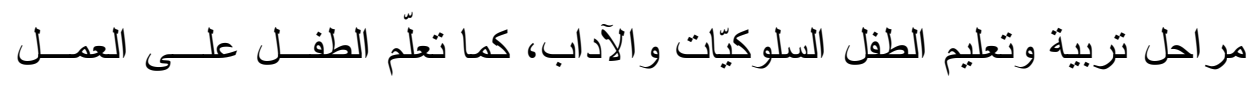

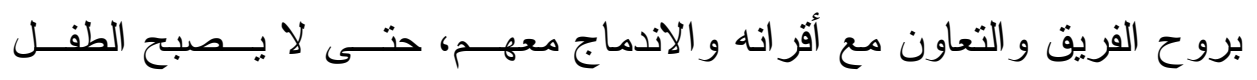

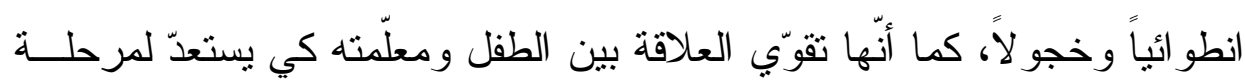

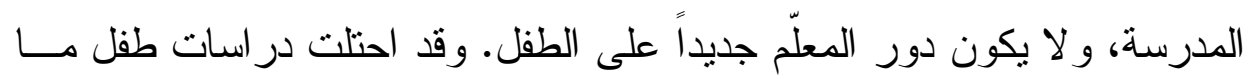

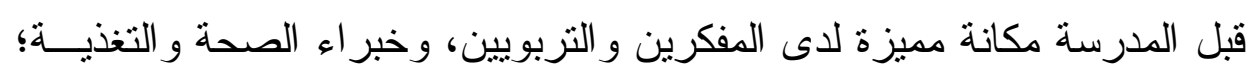
بغية تطوير الرياض من أجل تهيئة طفل ما قبل المدرسة.

ومرحلة الطفولة بصفة عامة - و الطفولة المبكرة بصفة خاصة - هــي

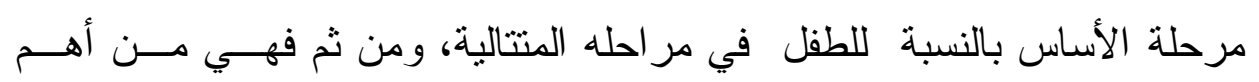

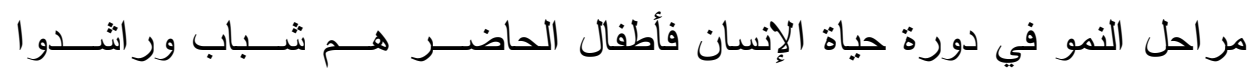

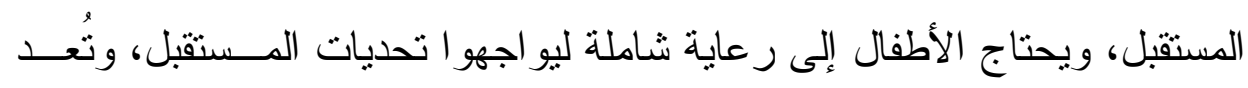

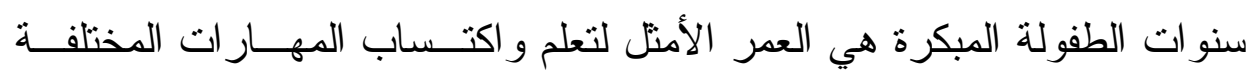
وذلك لأن الطفل في هذه المرحلة يستمتع بتكر ار أي عمل حتى يتمكن من إثقانه

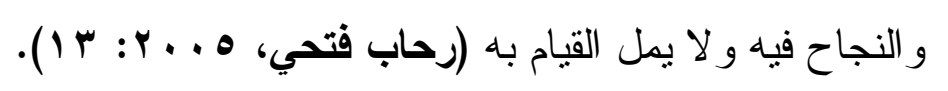

كما تُعد رياض الأطفال بيئة تربوية مكملة لدور الأسرة في تتشئة الطفـلـل

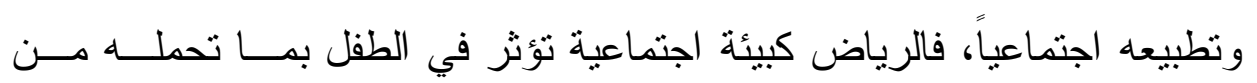
إمكانات وتفاعلات بينه وبين الأطفال، وبين العاملات فئها.

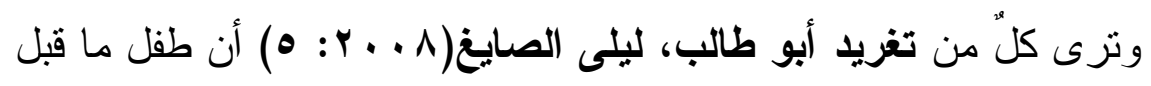

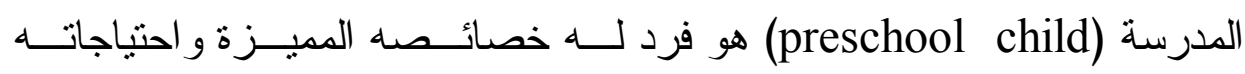


الخاصة التي يجب تلبيتها ليحقق الطفل النــــ المتكامـل، كـي يــتمكن مــن الانتقال إلى المر احل اللاحقة بسلامة، ويتراوح عمر هذا الطفل ما بين سن ثلاث

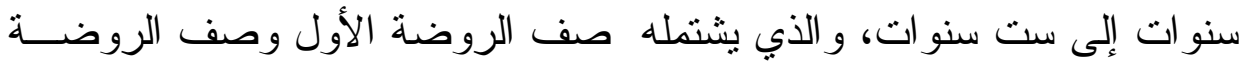
الثناني.

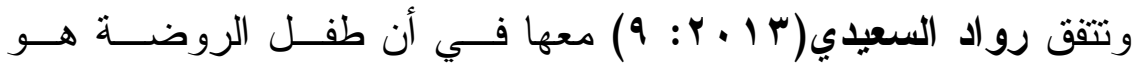
طفل في المرحلة العمرية الممتدة من نهاية العام الثالــث حتهى نهايـــة العــام

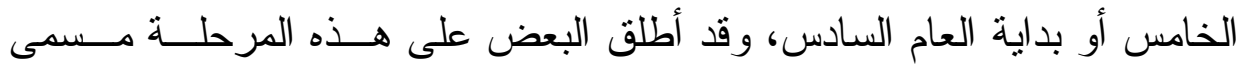

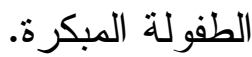

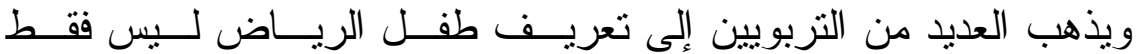

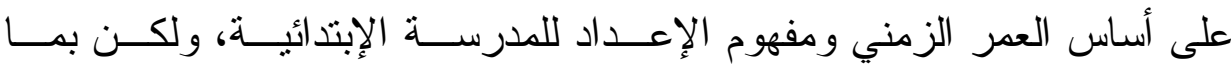

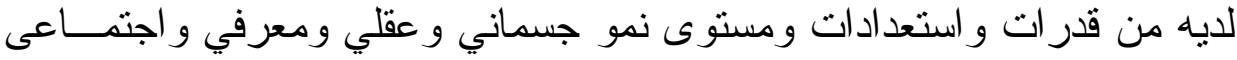

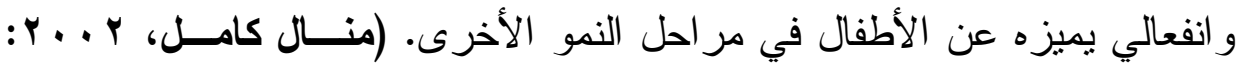

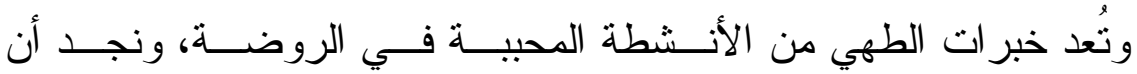

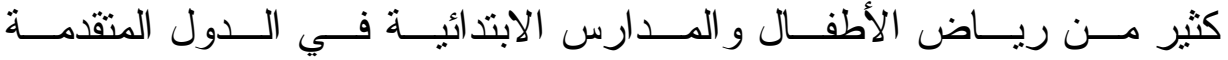
يدرجون الطهي كمادة أساسية في الدقرر الدراسـي، حيــث لا يمكـن إنكـــار

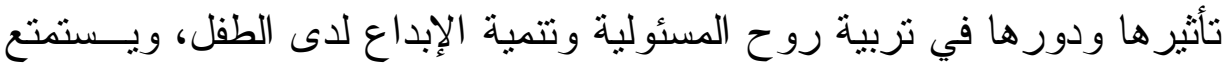

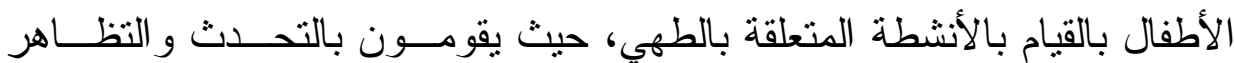

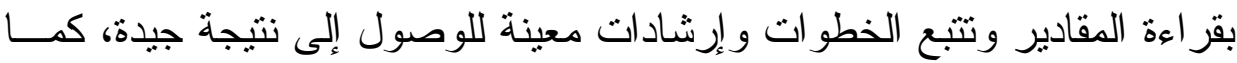

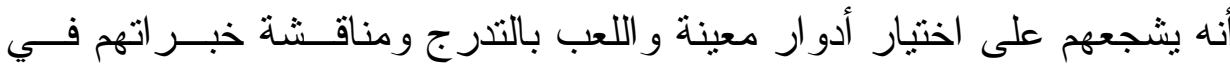
• (المطبخ 


$$
\text { ه تعلم طفل الروضة من خلا خبرات الطهي : }
$$

أوضح داربي شير (Darbyshire, Jo, 2004: 9) أن خبر ات الطهـي

ليست مجرد أنثطة لإعداد الطعام وتخزينه فحسب، بل يمكنها تقديم عدد غيـر الئر

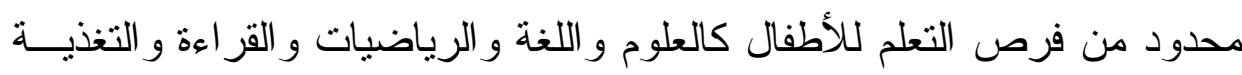

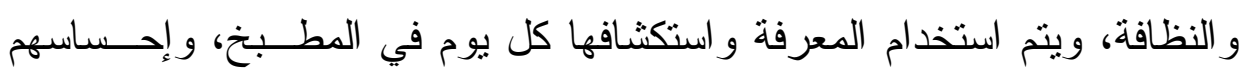

$$
\text { بالثقة في أنفسهم، ويكتسبون المثير من مهار ات الحياة. }
$$

ويستمتع الأطفال بالقيام بالأنثطة المتعلقة بخبر ات الطهي، حيث يقومــون

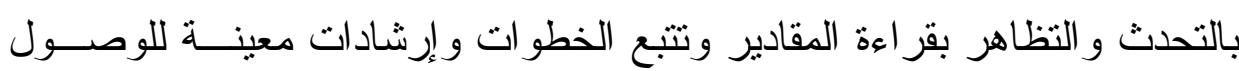

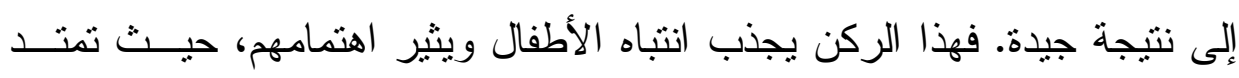

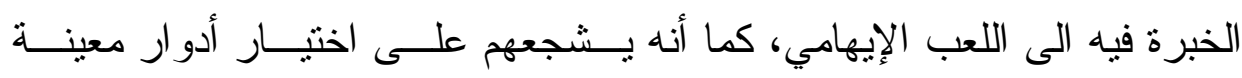

$$
\text { و اللعب بالتدر ج ومناقثنة خبر اتهم في المطبخ. }
$$

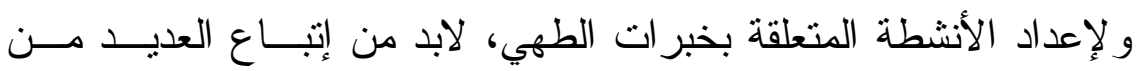

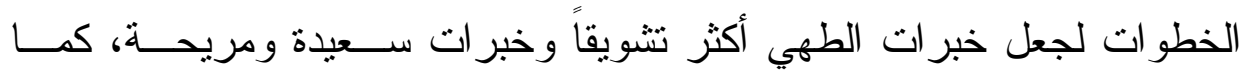

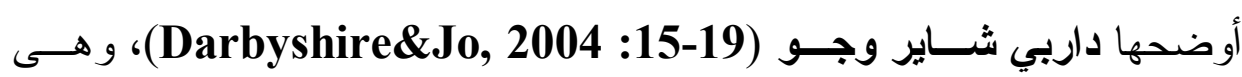

> نوفير طاو لات وكر اسى مريحة وأدوات في حجم الأطفال.

> مرعاة السلامة و الأمان للأطفال في المطبخ ، ونوقع بعـض المفاجـأت

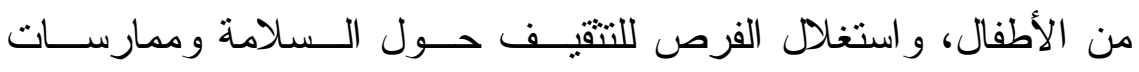

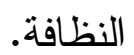

> تبادل المهار ات و المعرفة حتى يتمكنو ا من التعلم و الفهم.

r.r.r. العدد الثانى : أكتوبر

99

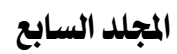


> تكليف الطفل بمهام صغيرة يستطيع المساعدة بها في المطبخ منل مسـح

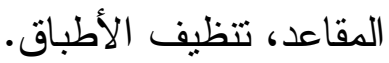

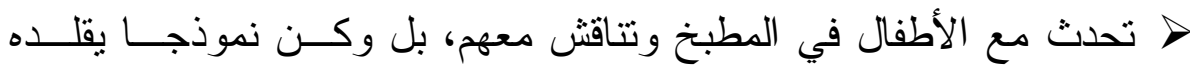

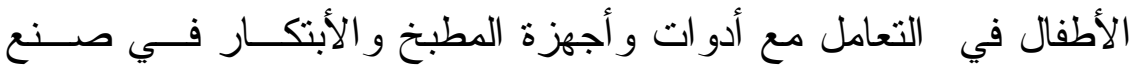

$$
\text { 口 أهمية خبرات الطهي : }
$$

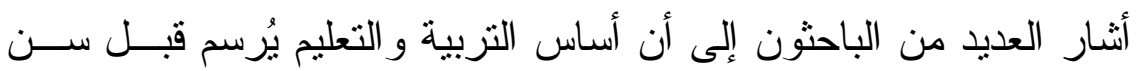

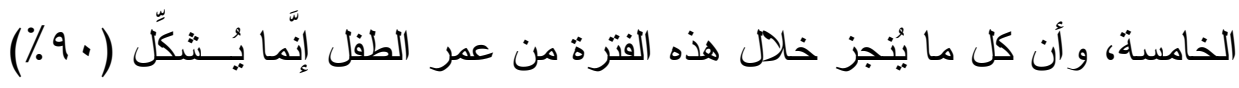

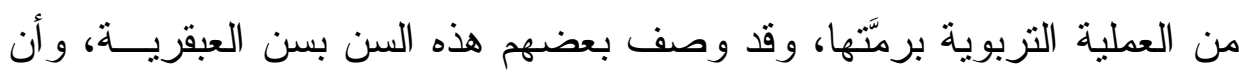
طفولة الإنسان تمنلك استعدادات خاصة يمكننا أن نستقيد منها فو ائد كثيرة.

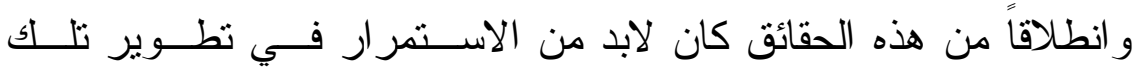
القدرات وتوجيهها بما يحقق الأهداف التربوية المطلوبة، ويضمن النمو الـسليم

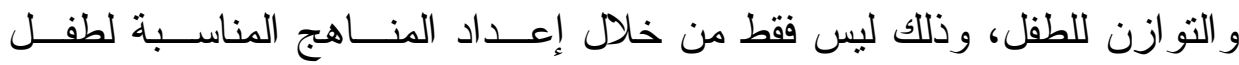

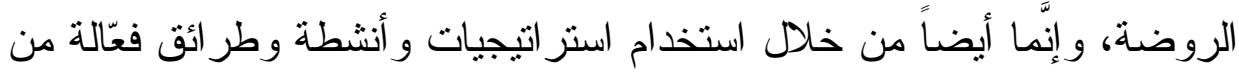

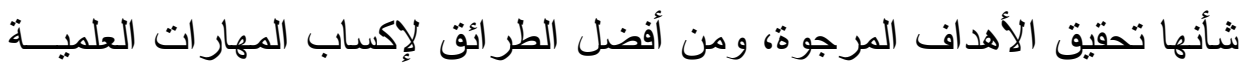

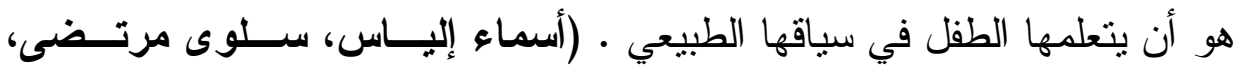

$$
\text { . (10:..0 }
$$

ومن هنا كان لخبرات الطهي وقع خاص في نفوس الأطفال، فضلاً عنَّــا

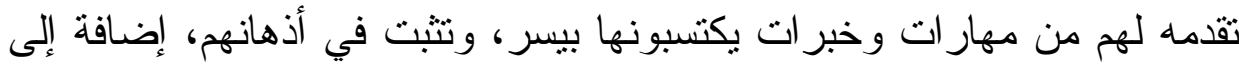

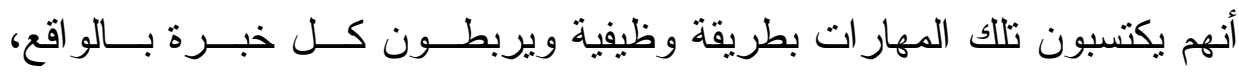

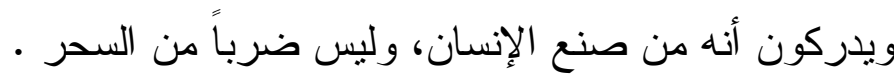


وحيث أن مرحلة رياض الأطفال تلعب دوراً أساسياً تجــاه الطفـل مــن

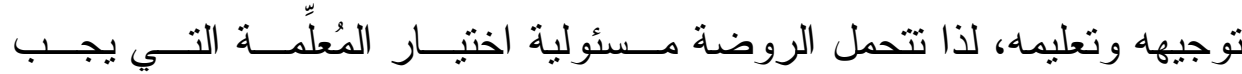
أن تكون على دراية بخصائص نمــو الطفـلـل فـي هــــهـ المرحلــة، وقــادرة على إكساب الأطفال السلوكيات و الاتجاهات الإيجابية تجاه المعارف و المهــار ات

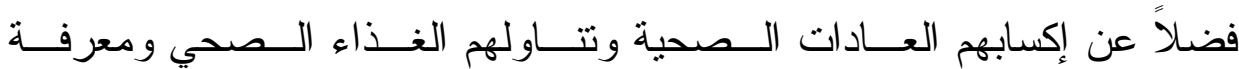
فو ائدة بصفة عامة، فالمعلّمة هي الأساس في عملية التطوير التربـــوي لتــشئة الأجيال، فهي ليست ناقلة للمعرفة، بل مبدعة ومبتكرة لأنشطة متتوعة، تـسعى التى من خلالها إلى تتمية كافة جو انب شخصية الطفل، وتثبيت المفاهيم لديهم، وتتمية

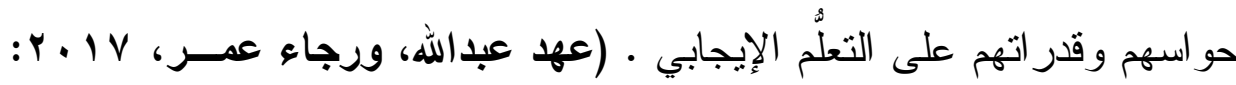

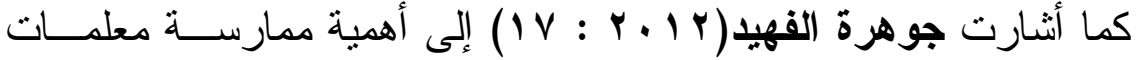

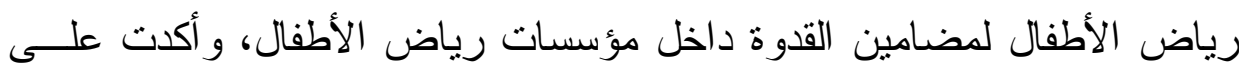
وجود علاقة بين عدد وجبات الطفل وبعض أنماط الــسلوك، ووجــود علاقــة بين نوعية وكمية غذاء الطفل وبعض قدر اته العقلية، و أثبتـــت الدر اســـة أيــضـاً وجود علاقة بين الوجبة الغذائية المتو ازنة و الــسلوك الـسوي للطفـلـ، و علــى الرغم من أهمية الوجبة الغذائية، إلا أن معلمات رياض الأطفال قــــ يُخصــصـ إنه

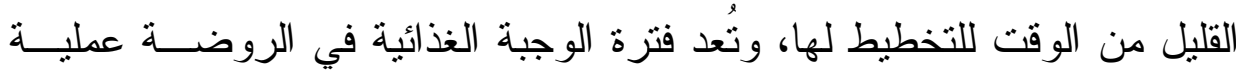

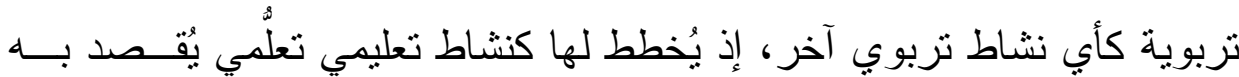

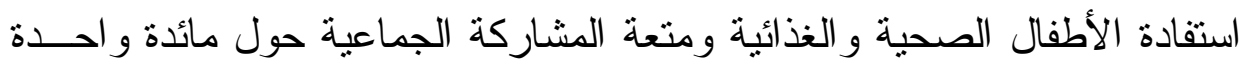

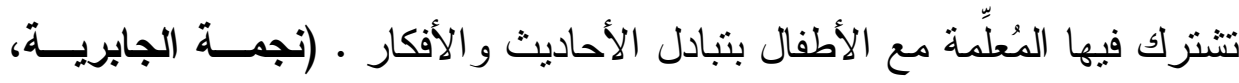


口 دور المعلمة في الإعداد لخبرات الطهي لطقل الروضة :

أنثار كـلـ" مــن بــوتني وآخـرون (Bottini ,et-al, 2005: 23) ،

مادسون (16: Madson, أن للمعلمة دور كبير في الإعداد لخبـر ات 2013

$$
\text { الطهي في الروضة يتمنت في الآتي : }
$$

> تحديد التصور المناسب لأنشطة خبرات الطهـى المتـضمنة ســوكيات

المفاهيم الرياضية المناسبة للطفل.

> در اسة المصادر و الإمكانيات المتاحة (الوقت - المال - المواد التعليميــة)

التى تساعد على التيسير العمل في مواقف خبر ات الطهى.

> تضمين سلوكيات المفاهيم الفرعية لمفهوم القيــاس التـي ســوف تتمــي

بو اسطة أنشطة خبر ات الطهى.

> تحديد أهداف و أنشطة كل مفهوم و التى على أساسها يتحدد بماذا وكيــف

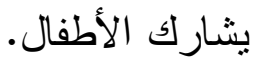

> تهيئة بيئة التعلم المناسب للطفل بهدف القيام بممارسات وتدرييات و ألعاب

لإكتساب السلوكيات المفاهيم الرياضية بو اسطة خبر ات الطهى.

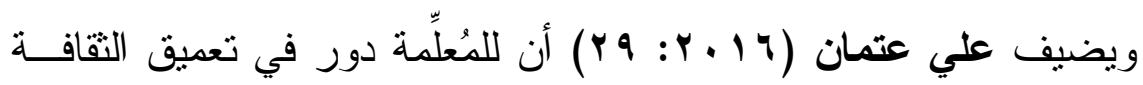

الغذائية لدى أطفال الروضة، من خلال ما يلي :

> تقديم المعلومات و المفاهيم الغذائية السليمة للطفـلـ، عبــر إثـــر اكه فــي

مجموعة من الأنشطة و البر امج اليومية، ونقل ما تعلمه إلى بيئته الممتدة.

> ربط مفاهيم الثقافة الغذائية بخبرات الطفل اليومية وسلوكياته الغذائية.

r.r. r.r

المجلد السابع 
خ تدريب الأطفال على إعداد وجبات غذائية صــحية منو ازنسة، بمسساعدة المُعلمّة. > طرح الأسئلة المتعلقة بالمو اقف الغذائية، وتتجيع الأطفال علـى اقتــراح حلول لها. > تشجيع الأطفال على استخدام حواسهم للتعرف علـى مكونــات الغــذاء

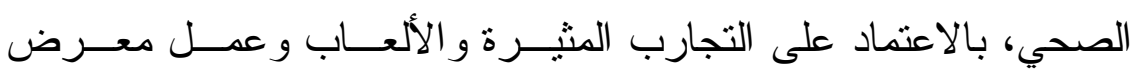

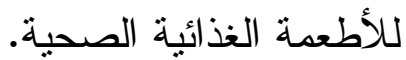

ه دور المُعلمّة في تنمية مفهوم القياس لدى طقل الروضة من خلا خبرات

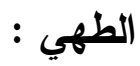

لمُعلمة رياض الأطفال دور مهم في إكساب مفهوم القيــاس لــدى طفــلـ

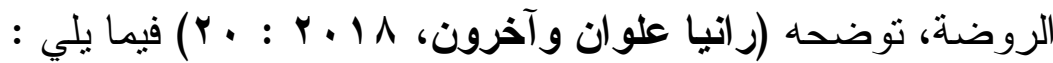

- مساعدة الطفل على الثعور بالثقة في النفس، من خلال اختيارهـا لعهــل في مستوى الطفل يقوم به بنجاح. - - تشجيع الطفل، و الاهتمام بمحاو لات الطفل وليس النتيجة. - مساعدة الطفل على مو اجهة الفثل بطرق إيجابية، بل جعل الفثل وسـيلة تعلُّم جديدة. - - الابتعاد عن استخدام أنثطة تتافسية بين الأطفال، والاهتمام والتركيز على الأنشطة التعاونية. - - توفير بيئة غنية بالمو اقف المتتوعة التي تثجع الطفل على الاستكثاف. r.r. r.r

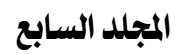


- - دعم الأطفال من خلال التعليقات و الأسئلة. - تشجيع الطفل على التعبير عن مشاعره، و أفكاره من خلال اللغة. - تحديد الأهداف التربوية لتدريس المفاهيم المر اد تحقيقها. - اختيار الطرق و الأساليب التي تتسجم مع المفهوم. - الاهتمام برسم صورة ذهنية للففهوم في عقول الأطفال من خلال إعطـــاء الأمتلة على الدفهوم. - الأنمام برسن. - - تحديد طبيعة المفهوم وتصنيفه. - تقويم تعلُّم الأطفال من خلال أسئلة للكثثف عن اكتساب المفاهيم. - - مر اعاة الفروق الفردية بين التلاميذ و أنماط تعلُّهم المختلفة. •

تُعتبر الرياضيات من العلوم الهامة التي لا يمكن الاستغناء عنها، فــالفرد

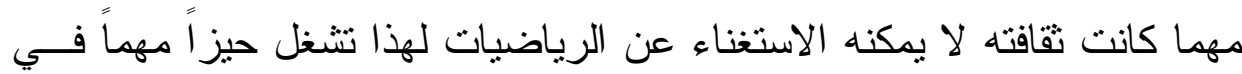

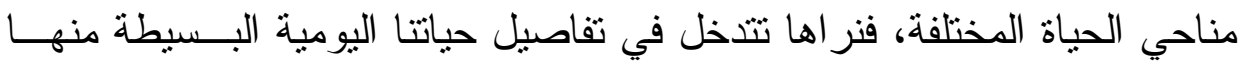

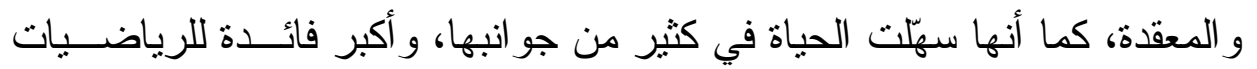

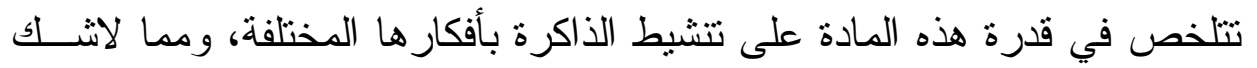
فيه أن الرياضيات بفروعها المختلفة قد ساعدت الإنسان منذ القدم وحتى وقتنــــا

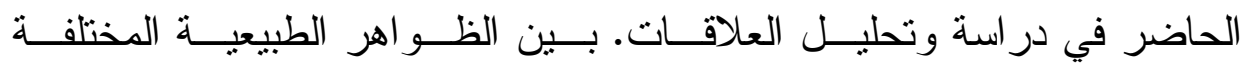

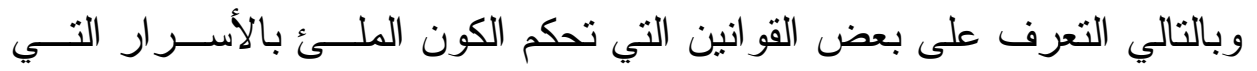

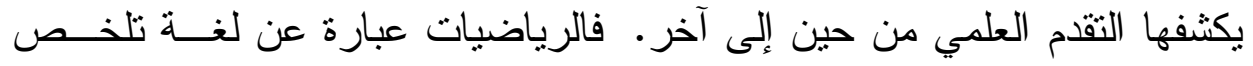


المشكلات الو اقعية و التعامل معها وكيفية حلها وتـساعدنا علــى فهـم عالمنـــا،

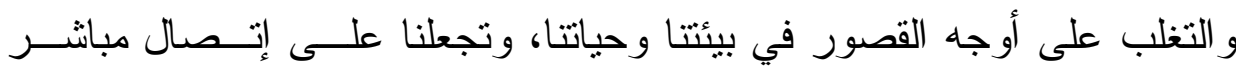

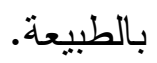

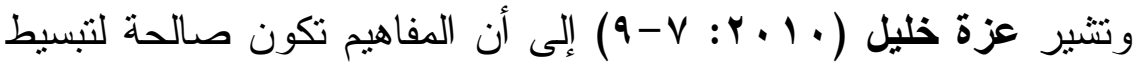

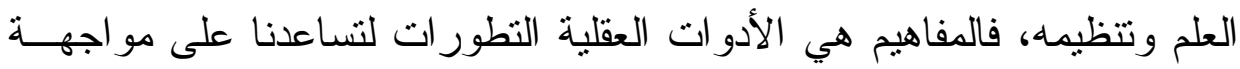

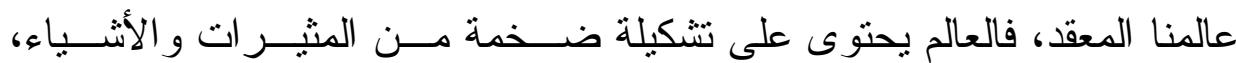

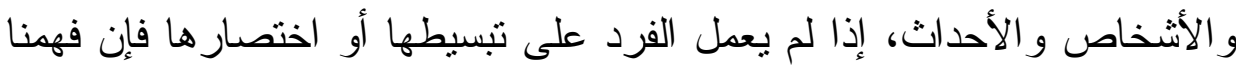

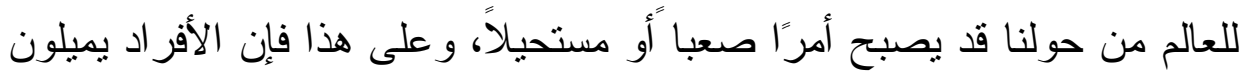

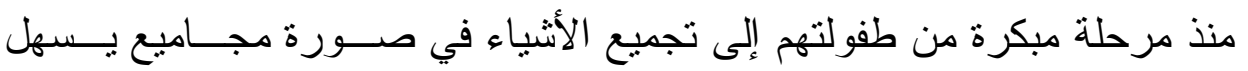

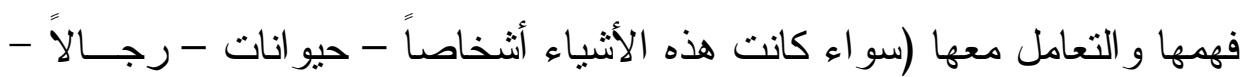

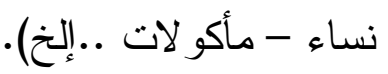
وقد أكدت نتائج العديد من الدراسات التي أُجريت فــى مجــال الدفــاهيم

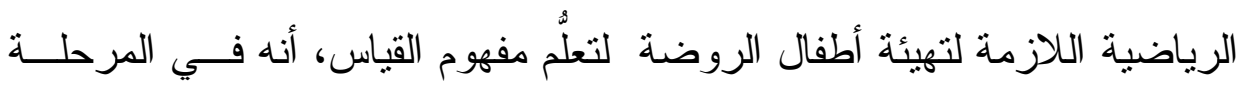
العمرية (ع - ؟) سنوات يوجد ارتباط بين مفهـوم القيــاس وبــاقى الدفــاهيم الرياضية على النحو التالى : التى - العلاقات المكانية : فوق - تحت، قريب - بعيد، أمام - خلــ - بــين،

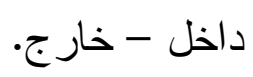
- علاقة الترتيب : أقصر - أطول، أقل - أقصر ، قبل - بعد. - مفاهيم ما قبل العدد : الانتماء، التتاظر الأحادي، التـصنيف، التشلــسل،

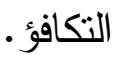


- مفهوم العدد : ويشمل العدد الترتيبي، العدد الكاردينالي، الرموز العددية،

$$
\text { المقارنة العددية، العد من ( ( - • ()). }
$$

- المفاهيم الهندسية : الأشكال الهندية (المربع - المستطيل - المتلــث -

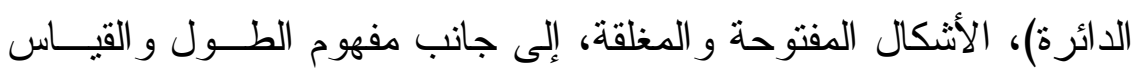

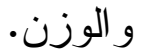

\section{口 تعريف مفهوم القياس :}

هي عملية استخدام تقدير ات أو مقاييس معيارية أو غير معياريـــة وأدوات

قياس مناسبة لوصف أبعـاد موضــوع مـــا أو حــدث فـي صــورة كميــة

.(Chiappetta \& Koballa, 2010)

كما أنها قدرة عقلية، تُمكِّن الفرد مــن اختيــار أداة القيــاس و الوحـــدات المناسبة للسمة التي يريد قياسها في ظاهرة طبيعية، ثم إعطـــاء قيمــة عدديـــة صحيحة ودقيقة وذلك باستخدام وحدات غير معيارية في بداية عملية القياس، ثم

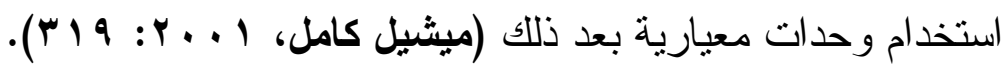

و هنالك ثناثة أنماط مختلفة من المقارنات تهنم بها عملية القياس كما أثنار

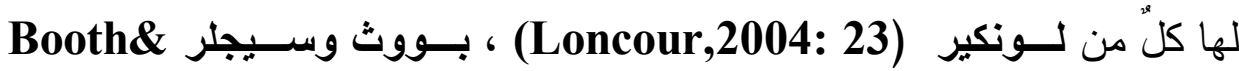
(Siegler, 2008: 12)

$$
\text { > مقارنة أحجام الأشياء. }
$$

لا مقارنة المساحات و السر عات و الأوز ان ودرجات الحر ارة.

$$
\text { > مقارنة الأوقات الخاصة بأحداث معينة. }
$$


فيمكن لطفل الروضة تعلم استخدام القياس حين تطلب المعلمة من الطفــلـ

أن يكتثف طول شيء ما داخل الفصل أو خارجة باستخدام أب شيء في متتاول

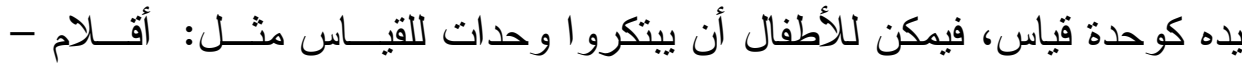

$$
\text { حبوب - أحبال - خطو ات القدم. }
$$

ويمكن الاستدلال علي القياس من خلا مجموعة من المؤشرات منها :

$$
\begin{aligned}
& \text { - - اختيار الأدو ات المناسبة للقياس. } \\
& \text { - استعمال أدو ات القياس بشكل صحيح. } \\
& \text { - - التعبير كمباً عن الخاصية المقاسة. } \\
& \text { - - الدقارنة بين الأشياء باستخدام أداة قياس مقنن. } \\
& \text { 口 المفاهيم الفرعية لمفهوم القياس : }
\end{aligned}
$$

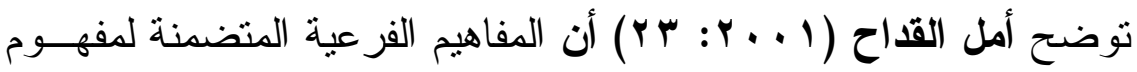

$$
\text { القياس هى : }
$$

أ. التقدير النسبي للقياسات البسيطة متل : الطول و الحجــم والــوزن بـدون

$$
\text { إستخدام أدو ات قياس معيارية. }
$$

ب. إستخدام مصطلحات للتعبير عن خواص الأثشياء المقاسة و المقارنة بينهما

$$
\text { منل (أطول من/ أقصر من / أكبر من / أصغر من / و هكذا من ل...). }
$$

ج. التعرف على بعض أدوات القياس غير المعيارية التى يمكـن اســتـذامها في قياس خو اص بعض الأثشياء.

د. استخدام أدوات قياسية متتوعة - غير معيارية - لإجر اء عمليــة قيـاس

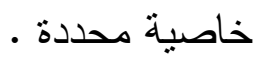

المجلد السابع


ويمكن استخدام خبرات الطهى في تنمية مفهوم القياس من خلا :

قيام المعلمة بتجهيز المكان المناسب بكل ما يحتاجه الطفل لتتمية مفهـوم القياس متل : توفير أدو ات غير مقننة للقياس مثـل شـــوك، معــالق، ســكاكين و غير ها، وكذللك ميز ان ليستخدمة الطفل في قياس الأوزان وغيرهــا فــالمطبخ

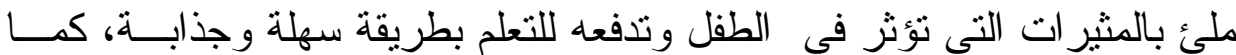

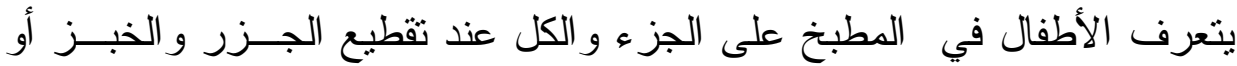
يقيسون كأس من الدقيق، وقد يستخدم الأطفال مقاييس أخرى للمو اد مثل ملعقــة كبيرة، وتتطور قدرة الطفل على القياس إلى قياس الزمن وتتبعه وكذلك درجــة الحر ارة و الأوزان للمقادير وغير ها من خلال إعداد الكيك.

$$
\text { • فروض الاراسة : }
$$

() نوجد فــروق ذو دلالــة إحـصائية بــين منوسـطي درجـات أطفــال

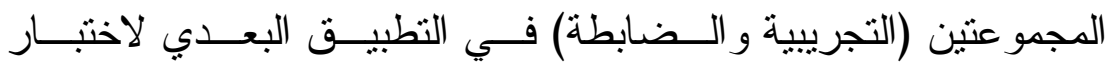

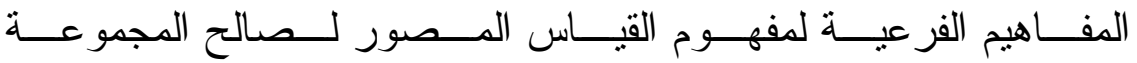
التجريبية.

r توجد فروق ذو دلالة إحصائية بين متوسطي درجات أطفال المجموعــة

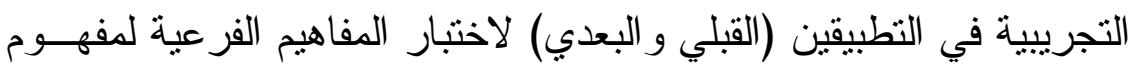

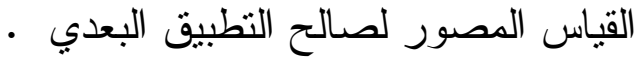
ץ) يحقق تدريس البرنامج المقترح فاعلية كبيرة باستخدام مربع إيتا سـكوير

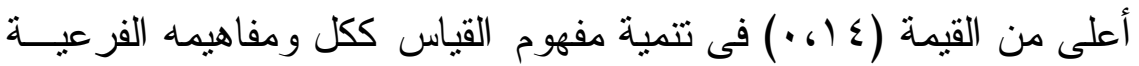

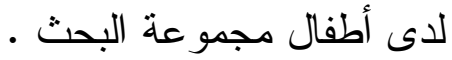




\section{• منهج الار اسة والتصميم شبه التجريبي :}

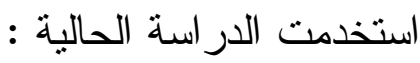

( ) المنهج الوصفي التحليلي : لإعداد الإطار النظري و إعداد قائمة المفاهيم

الفرعية لمفهوم القياس المر اد تتميتها لــدى طفــلـ الروضــــة وتــصميم

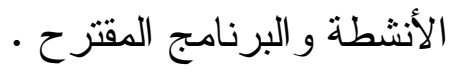

r) المنهج التجريبي والتصميم شبه التجريبي : (الذي بعتمد علـى وجــود

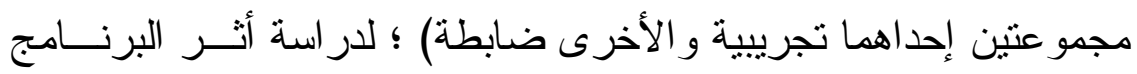

المقترح القائم على استخدام خبر ات الطهي في تتمية مفهوم القياس لــدى

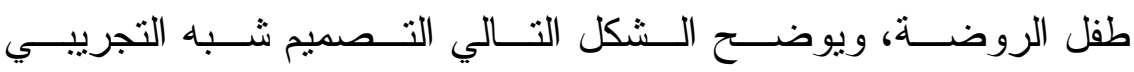

$$
\text { للدر اسة : }
$$

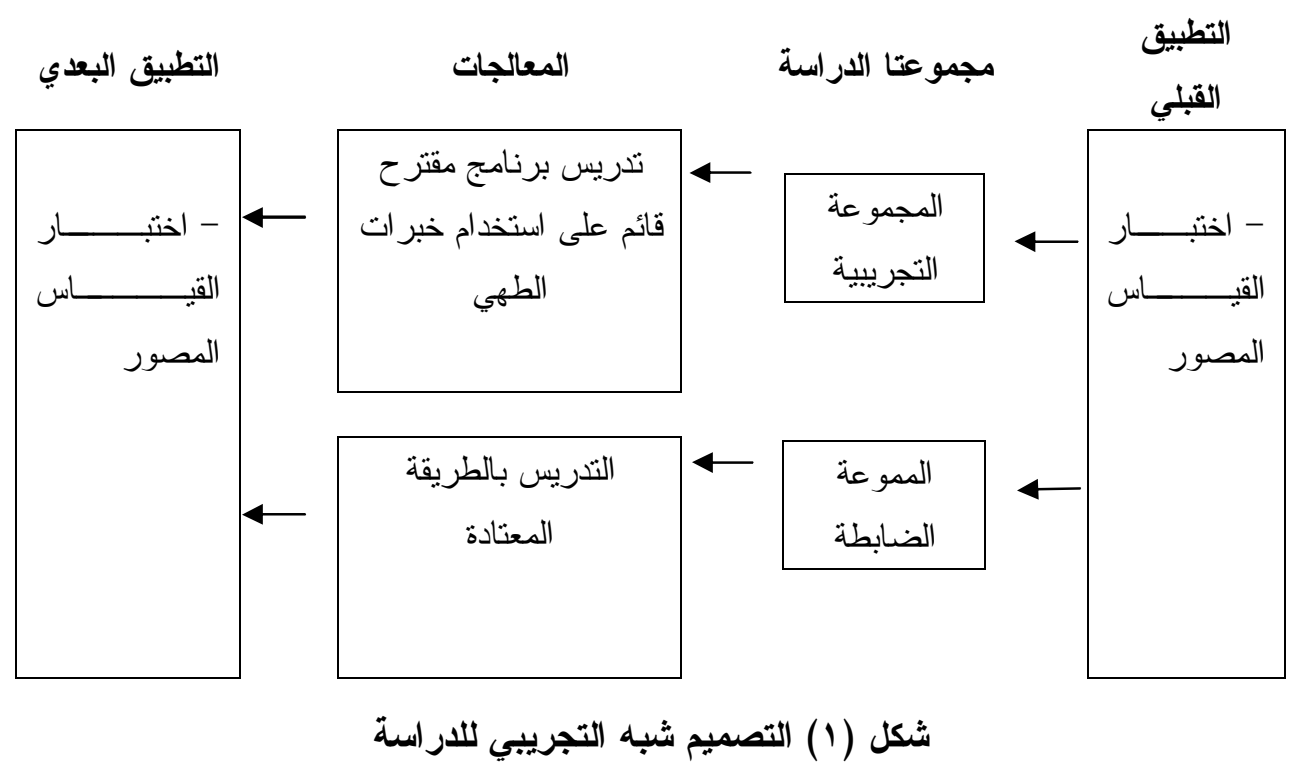

العدد الثانى : أكتوبر •r.r

1.9

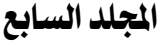




$$
\text { - متغير ات الار اسة : }
$$

وقد إثتنمل التصميم شبه التجريبي على المتغير ات التالية : > المتغير المستقل : خبرات الطهي • >

$$
\text { - عينة الار اسة : }
$$

تم اختيار عينة الدر اسة من أطفال المستوى الثــاني لريــاض الأطفـــال تنتر اوح أعمار هم ما بين (0-7) سنو ات، حيث تم تقـسيمهم إلــى مجمـــوعتين

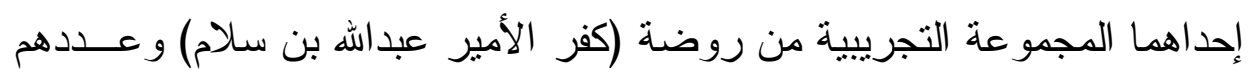
( • (r)، و الآخرى المجموعة الضابطة من أطفال روضة(مجمع رياض أطفال تاج

$$
\begin{aligned}
& \text { العز) و عددهم ( • (r) • } \\
& \text { مواد وأدوات الدر اسة : }
\end{aligned}
$$

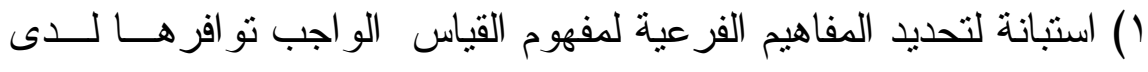
طفل الروضة .(إعداد الباحثة).

r) البرنامج المقترح القائم على استخدام خبر ات الطهي. (إعداد الباحثة) .

$$
\begin{aligned}
& \text { r) اختبار مفهوم القياس المصور (إعداد الباحثة). } \\
& \text { إجراء تطبيث تجربة البحث : }
\end{aligned}
$$

للإجابة عن أسئلة البحث و التحقق من صحة الفروض تم إتباع الإجر اءات

ثخ اولا" : الإطلاع على الدراسات السابقة والأدبيات المتعلقة بمفهوم القياس لتحديد المفاهيم الفرعية لمفهوم القياس لطقل الروضة . 
• ثانيا" : إعداد قائمة بالمفاهيم الفرعية لمفهوم القياس المناسب تنميتها

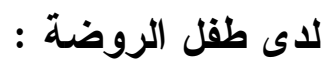

$$
\text { للإجابة على السؤال الأول من أسئلة البحث وهو : }
$$

" ما المفاهيم الفرعية لمفهوم القياس المناسب تتميتها لاى طفل الروضة ؟ "

تم إعداد القائمة وفقاً للإجر اءات النالية :

(1) تحديد الهدف من إعداد القائمة .

r) إعداد الصورة الأولية للقائمة .

r) تطبيق استبانة المفاهيم الفرعية لمفهوم القياس على مجموعة من معلمات

$$
\text { ومشرفات رياض الأطفال . }
$$

ويمكن توضيح الإجر اءات بالتفصيل فيما يلي :

( ) تحديد الهدف من إعداد القائمة :

تهدف القائمة إلى تحديد المفاهيم الفرعية لدفهوم القياس المناسب تتميتها

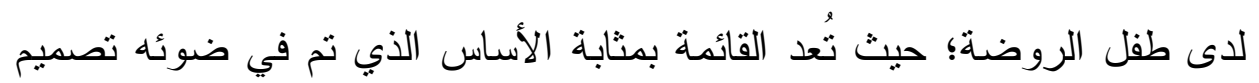

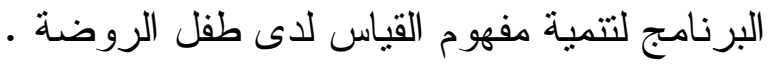

Y ) إعداد الصورة الأولية للقائمة : ب

تم إعداد الصورة الأولية للقائمة من خلال : - الإطلاع على الأدبيات و البحوث و الدراسات السابقة التي تناولت مفهوم

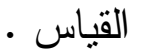


- - - مصائص طفل الروضة . - -

ومن خلال ما سبق استطاعت الباحثة إعــداد الــصورة الأوليــة لقائمـــة

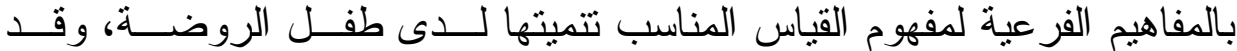
اشتملت الصورة الأولية للقائمة على أربعة مفاهيم فرعية يندرج تحت كل مفهوم مجموعة من العبار ات الفرعية؛ كما يتضح من الجدول التالي :
جدول (1)

\begin{tabular}{|c|c|c|c|}
\hline لكل مفهوم رئيسة الوزن النسبي & الفرعية لكل مفهوم العبارات & المفاهيم الفرعية & b \\
\hline ro & $\wedge$ & التقدير النسبي للقياسات البسيطة & 1 \\
\hline ro & $\wedge$ & استخدام المصطلحات & r \\
\hline ro & $\wedge$ & التعرف على بعض أدوات القياس غير المعيارية & $r$ \\
\hline ro & $\wedge$ & استخدام أدو ات قياسية متتو عة & $\varepsilon$ \\
\hline $1 \ldots$ & mr & المجموع & \\
\hline
\end{tabular}

تم تضمين القائمة فى صورتها الأولية فى صورة استبانة؛ والتى هدفت

إلى تحديد مدى أهمية المفاهيم الفرعية لمفهوم القياس لطفل الروضة من خلال مقياس متدرج (هام بدرجة كبيرة، هام بدرجة متوسطة، هام بدرجة ضعيفة،

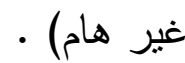

وقد تم عرضها فى صورتها الأولية على مجموعة من المحكمين من أعضاء هيئة التدريس من الجامعات المصرية تخصص مناهج وبر امج الطفل و علم النفس، وقد أقرو ا جميعاً أهمية هذه المفاهيم لطفل الروضة مع تعديل بسيط فى صياغة بعض المفاهيم الفرعية .

r.r. العدد الثانى : أكتوبر 


\section{؛) تطبيق استبانة المفاهيم الفرعية لمفهوم القياس :}

تم تطبيق استبانة المفاهيم الفرعية لمفهوم القياس؛ لحصر آراء معلمات ومديرات ومشرفات رياض الأطفال و أولياء أمور الأطفال( . . 1 فرد) حول أهم المفاهيم الفرعية لمفهوم القياس المناسب تتميتها لدى طفل الروضة، و الجدول التالى يوضح ذلك :

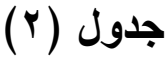

(آراء العينة حول المفاهيم الفرعية لمفهوم القياس المناسب تتميتها لاى طقل الروضة (ن = ())

\begin{tabular}{|c|c|c|c|c|c|c|c|c|c|}
\hline & & & & & \multicolumn{3}{|c|}{ الاستجابات } & \multirow{3}{*}{ المفاهيم الفرعية } & \multirow{3}{*}{ b } \\
\hline هام & غير & ضة" & بامجة & متوسطة & بدرجة & كبيرة & بامجة & & \\
\hline$\%$ & ك & $\%$ & ك & $\%$ & ك & $\%$ & ك & & \\
\hline 1 & 1 & $\varepsilon$ & $\varepsilon$ & 0 & 0 & 9. & 9. & التقدير النسبي للقياسات & 1 \\
\hline$v$. & $v$. & 0 & 0 & 0 & 0 & $r$. & $r$. & استخدام المصطلحات & r \\
\hline 0 & o & 0 & 0 & r & $r$ & AV & AV & التعرف على بعض أديارية & $r$ \\
\hline . & 1. & 1. & 1. & 0 & 0 & vo & vo & استخدام أدوات قياسية & $\varepsilon$ \\
\hline
\end{tabular}

من البيانات الواردة فى الجدول السابق و الخاص باستجابات أفر اد العينة، و التى بلغ عددهم ( . (1) من (معلمات ومشرفات ومديرات رياض الأطفال، وأولياء أمور أطفال الروضة) حول المفاهيم الفرعية لمفهوم القياس المناسب تتميتها لدى طفل الروضة يتضح الآتي : 
> احتل الدفهوم الفرعي " التقير النسبي للقياسات البسيطة " المرتبة الأولى بنسبة تكر ارية بلغت ( 9 \% \% من حيث درجة الأهمية " بدرجة

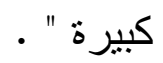

> احتل المفهوم الفرعي " التعرف على بعض أدوات القياس غير المعيارية"

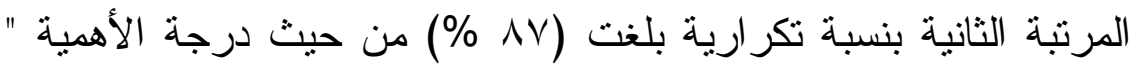

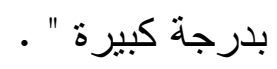

> احتل المفهوم الفرعي " استخدام أدوات قياسية متنوعة " المرتبة الثالثة بنسبة تكر ارية بلغت (V0 \% من حيث درجة الأهمية " بدرجة كبيرة " . > احتل المفهوم الفرعي " استخدام المصطلحات " المرتبة الأخيرة بنسبة

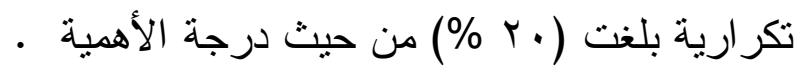

يتضح مما سبق إجماع أفراد العينة حول أهمية المفــاهيم الفرعيــة لمفهـوم

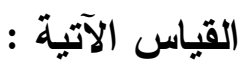
( ) التقدير النسبي للقياسات البسيطة

$$
\begin{aligned}
& \text { r التعرف على بعض أدو ات القياس غير المعيارية . } \\
& \text { r) استخدام أدو ات قياسية متتوعة . }
\end{aligned}
$$

و هذه المفاهيم الفرعية الثناثة لمفهوم القياس هى التي تم تتمينها من خلال البرنامج المقترح القائم على استخدام خبرات الطهي، وبذلك تكون تمت الإجابة على السؤ ال الأول من مشكلة البحث وهو :

" ما المفاهيم الفرعية لمفهوم القياس المناسب تنميتها لاى طفل الروضة ؟ " 
- ثالثا" : إعداد برنامج مقترح قائم على استخدام خبرات الطهي :

للإجابة على السؤال الثاني من أسئلة البحث وهو :

"ما البرنامج المقترح القائم على استخدام خبرات الطهي الأي ينمي مفهوم

القياس لاى أطفال الروضة ؟"

$$
\text { تم القيام بالإجر اءات التالية : }
$$

( ) تحديد أسس إعداد البرنامج المقترح :

$$
\text { تم إعداد البرنامج المقترح فى ضو ء الأسس التالية : }
$$

> قائمة المفاهيم الفرعية لمفهوم القياس المناسب تتميتها لدى أطفال الروضة

$$
\text { (تم إعدادها مسبقاً). }
$$

> و اقعية البرنامج من حيث منطلبات تتفيذه؛ حيث روعي عند إعداده أن تكون متطلبات تتفيذه و اقعية وممكنة من حيث الزمن و الإمكانات متاحة

$$
\text { لتنفيذه . }
$$

> مر اعاة المرونة الكافية عند إعداد البرنامج المقترح بإخال التعديلات

$$
\text { اللازمة ليو اكب خصائص أطفال الروضة . }
$$

> التتوع فى الوسائل، المواد والأدوات و الأنشطة المستخدمة أثناء تتفيذ

$$
\text { البرنامج حتى يتحقق الهدف منه . }
$$

ץ ) تحديد الهدف العام للبرنامج المقترح :

تم تحديد الهدف الرئيسي للبرنامج المقترح وهو تتمية المفاهيم الفرعية لمفهوم القياس لدى أطفال الروضة من خلال استخدام خبرات الطهي .

r.r. المجلد السابع


r يتقر ع من الهدف العام للبرنامج ثلاثة من أهداف خاصة وهى : - تتمية مفوم " التقدير النسبي للقياسات البسيطة " لدى طفل الروضة . - تتمية مفهوم " التعرف على بعض أدوات القياس غير المعياريــة " لــدى

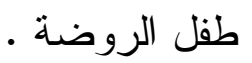

- تتمية مفهوم " استخدام أدوات قياسية متنوعة " لدى طفل الروضة . ؛ ؛ ) محتوى البرنامج المقترح :

تم تحديد محتوى البرنامج المقترح فى صورة موديولات تعليمية بالاستعانة بقائمة المفاهيم الفرعية لدفهوم القياس المناسب تتميتها لدى طفل

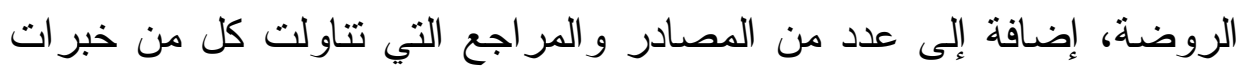

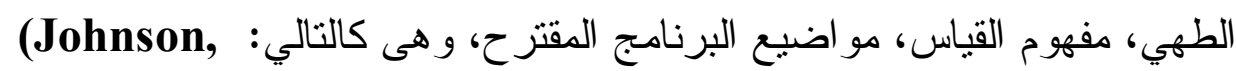

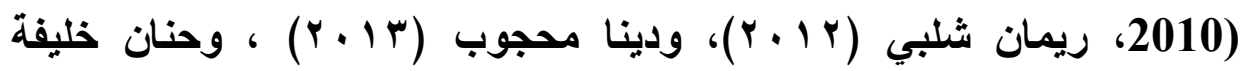

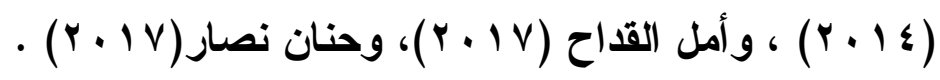
وقد روعى عند اختيار المحتوى ما يلي :

- أن يرتبط المحتوى بالأهداف الخاصة للبرنامج المقترح المحددة سابقاً . - أن تسهم المادة العلمية فى تتمية مفهوم القياس لدى أطفال الروضة . - أن تتعدد مستويات المحتوى وفقاً للفروق الفردية بين أطفال الروضة . - أن تكون المادة العلمية ذات تسلسل منطقى ومنظم . - أن بتضمن أنشطة وتدريبات منتو عة . 


$$
\begin{aligned}
& \text { 0) مكونات البرنامج المقترح : } \\
& \text { - مقدمة } \\
& \text { - - الأهداف العامة للبرنامج - } \\
& \text { - - الأهداف الخاصة للبرنامج - } \\
& \text { - الأدوات و الوسائل المستخدمة فى تتفيذ البرنامج • } \\
& \text { - الأنشطة المستخدمة فى تتفيذ البرنامج - } \\
& \text { - - الخطة الزمنية لتنفيذ الأنشطة . }
\end{aligned}
$$

- أنشطة البرنامج وعددها (·r) نشاط، وكل نشاط يتكون من (اسم

النشاط، الأهداف الإجرائية، المكان، الزمن، المفهوم الفرعي المراد

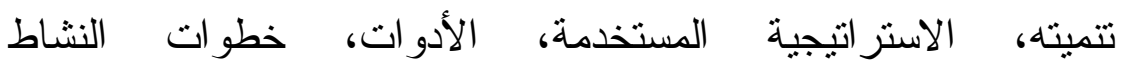

$$
\text { (الإجر اءات)، التقويم) (التهر) }
$$

1) عرض البرنامج المقترح على المحكمين :

بعد الانتهاء من صياغة البرنامج بصورته الأولية، تم عرضه على مجموعة من السادة المحكمين من أعضاء هيئة التذريس في الجامعات المصرية تخصص مناهج وبرامج الطفل وعلم النفس؛ وذلك للتعرف على آرائهم وملاحظاتهم حول البرنامج من حيث وضوح العنوان و الأهداف وارتباطها بالمحتوى، ومدى مناسبة المحتوى وصحة مادته العلمية و اللغوية وطريقة عرضه و الوسائل المستخدمة فى أساليب التقويم، وتعديل و إضافة ما يرونه مناسباً، وفى ضو ء آر ائهم ومقترحاتهم وتعديلاتهم .

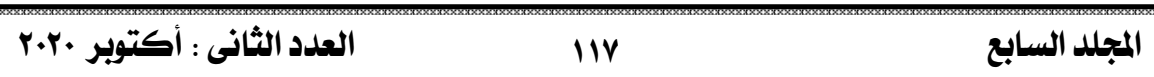


و أصبح البرنامج القائم على استخدام خبرات الطهي في صورته النهائية يتكون من (r) مفهوم فرعي، ( • (r) نشاط كما يوضحه الجدول التالي :

\begin{tabular}{|c|c|c|}
\hline عدد الأشطة & المفهوم الفرعي & م \\
\hline 1. & التقدير النسبي للقياسات البسيطة & 1 \\
\hline 1. & التعرف على بعض أدوات القياس غير المعيارية & $r$ \\
\hline 1. & استخدام أدوات قياسية متنوعة & $r$ \\
\hline$r$. & $r$ & مج \\
\hline
\end{tabular}

وبذلك تمت الإجابة على السؤال الثاني من أسئلة البحث و الذي ينص على : " ما البرنامج المقترح القائم على استخدام خبرات الطهي لتنمية مفهوم القياس لاى أطفال الروضة ؟ خ رابعا" : إعداد اختبار القياس المصور : للإجابة عن السؤ ال الثالث من أسئلة البحث، الذي نص على : ما فاعلية برنامج مقترح قائم على استخدام خبرات الطهي فى تنمية مفهوم القياس لاى أطفال الروضة ؟

تم بناء اختبار القياس المصور للى طفل الروضة، ووفقاً للإجر اءات التالية : () تحديد اللهدف من المقياس : يهدف اختبار القياس المصور إلى قياس مستوى الأطفال عينة البحث فى بعض المفاهيم الفرعية لمفهوم القياس بعد در استهم البرنامج المقترح القائم على استخدام خبر ات الطهي . 


$$
\text { : تحديد وصياغة عبارات الاختبار (T) }
$$

تم تحديد وصياغة عبار ات اختبار القياس المصور من خلال الإطلاع

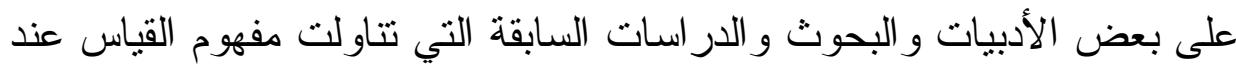

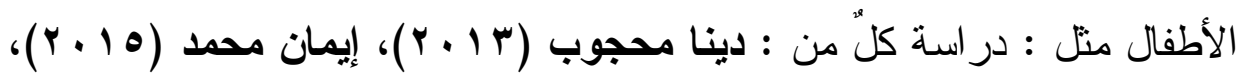

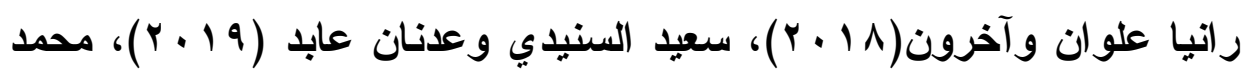

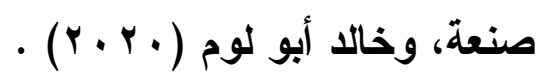

وقد تم بناء اختبار القياس المصور فى ضوء أهم ثلاثة مفاهيم فرعبة

لمفهوم القياس، وروعى عند صياغة أسئلة الاختبار المصور ما يلى :

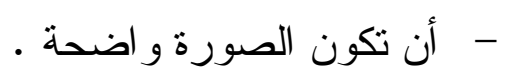

- أن تكون اللغة المستخدمة مناسبة لطفل الروضة ـ أرونه

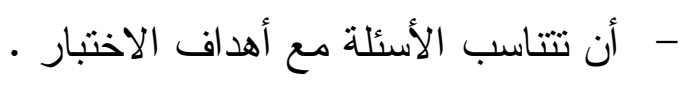

\begin{tabular}{|c|c|c|c|}
\hline 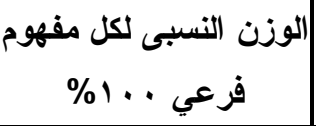 & عفهوم فرعي الأسئلة لكل & المفاهيم الفرعية لاختبار & p \\
\hline Trgt & $\wedge$ & التقدير النسبي للقياسات البسيطة & 1 \\
\hline Trgt & $\wedge$ & | التعرف على بعض أدوات القياس غير المعيارية & r \\
\hline מש, & $\wedge$ & استخدام أدوات قياسية متنوعة & $r$ \\
\hline$\% 1 \ldots$ & ك ب بؤالاً & المجموع الكلى & \\
\hline
\end{tabular}

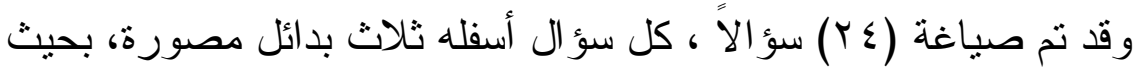

يختار الطفل البديل الصحيح ؛ كما فى الجدول التالى :

جدول (؛) : عدد الأسئلة في اختبار القياس المصور 


\section{r) التحقق من صدق الاختبار ( صدق المحكمين ) :}

قامت الباحثة بعرض اختبار القياس المصور بـصورته الأوليــة علــى

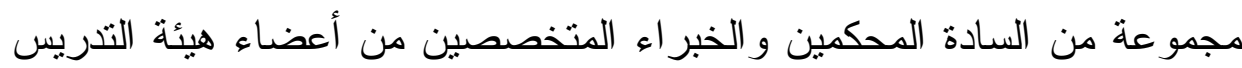

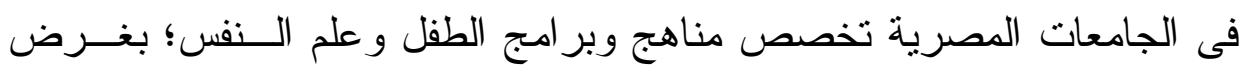

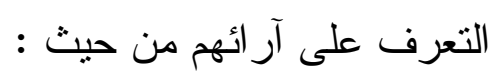

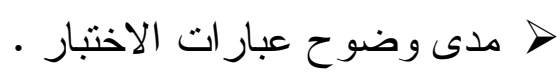

> مدى انتماء وقياس المفاهيم الفرعية لمفهوم القياس الرئيسي .

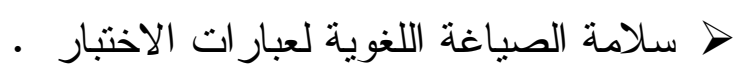

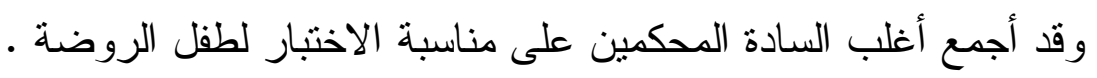
؛) التجربة الاستطلاعية للاختبار :

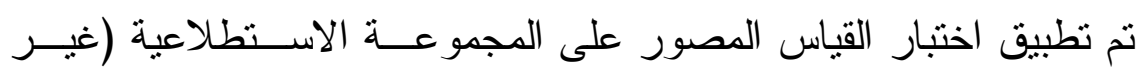

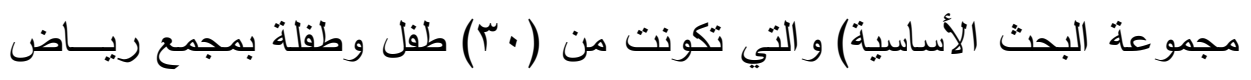

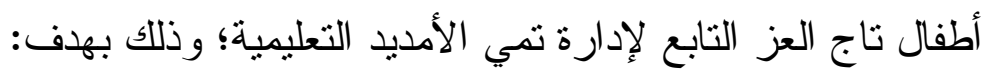

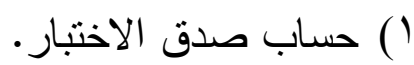

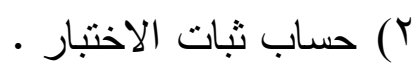

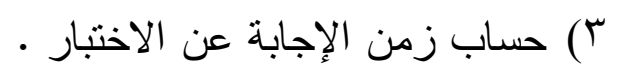

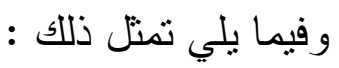
1) حساب الصدق " التجانس الداخلي " : تم حساب صدق الإتساق الداخلي لاختبار القياس المصور، بحساب معامل

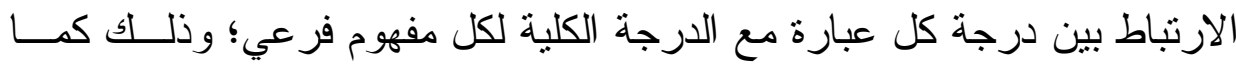

$$
\text { يوضحه جدول (7) : (7) }
$$


جدول (؟) : معاملات الارتباط بين درجة كل عبارة من أسئلة

الاختبار مع الارجة الكلية لكل مفهوم فرعي

\begin{tabular}{|c|c|c|c|c|c|c|c|}
\hline مستوى الدلاية & معامل الارتباط & رقم & الففهوم & مستوى الدلالة & معامل الارتباط & رقم & الففهوم \\
\hline & $* * ., 6 \leqslant \leqslant 7$ & IV & & & $* * .6 \vee .0$ & 1 & \\
\hline & $* * .69 r 9$ & 11 & & & $* * 6>10$ & r & \\
\hline & $* * .01 \mathrm{~V}$ & 19 & & & $* * .6 \mathrm{~V}$ & $r$ & \\
\hline & $* * .6 \vee \varepsilon$. & $r$. & استخد ام & & $* *$. ،VY & $\varepsilon$ & التقدير النسبي \\
\hline .6 .0 & $* *$. ( T) & r) & أدوات & .6 .0 & $* * .00 \leq 1$ & 0 & للقياسات \\
\hline & $* *$. เ $\leqslant 79$ & rr & قياسية متتوعة & & $* * .6 \vee 09$ & 7 & \\
\hline & $* * .67 \wedge 1$ & Tr & & & $* * .0 \wedge \Lambda$ & V & \\
\hline & $* *$. เ $\vee \wedge$. & $r \varepsilon$ & & & *** • • & $\wedge$ & \\
\hline & & & & & *** & 9 & \\
\hline & & & & & * * r vor & 1. & \\
\hline & & & & & $* * 6770$ & 11 & التعرف على \\
\hline & & & & & $* *$. $\vee 07$ & ir & بعض أدوات \\
\hline & & & & & $* * .67) \mathrm{V}$ & $1 \pi$ & القياس \\
\hline & & & & & $* * .6 V V V$ & $1 \varepsilon$ & غير المعيارية \\
\hline & & & & & $* .6010$ & 10 & \\
\hline & & & & & $* * .60$ & 17 & \\
\hline
\end{tabular}

(*) دال عند 0 ., •

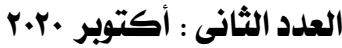


من خلال النتائج التى أسفرت عنها معاملات الارتباط، يتضح أن جميع

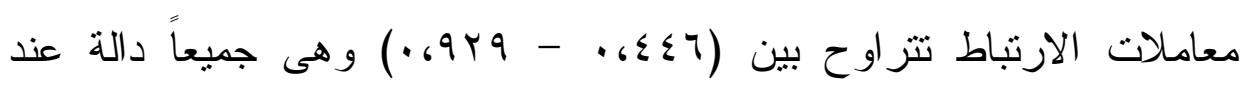
مستوى (0 •، • ) وبالتالى فإن أسئلة الاختبار تتجه لقياس درجة كل سؤال من المفاهيم الفرعية لاختبار القياس المصور ل r يُقصد بثبات الاختبار أن يُعطي الاختبار نفس النتائج ثقريباً إذا ما أعيد تطبيقه أكثز من مرة على نفس الأفراد تحت نفس الظروف، وقد تم استخدام طريقة ألفا كرونباخ لحساب معامل الثبات لاختبار القياس المصور، وهى كما :يلي

طريقة ألفا كرونباخ بعد تطبيق اختبار القياس المصور على مجموعة التجربة الاستكثافية، تم حساب معامل الثبات باستخدام معادلة ألفا كرونباخ، ووُجد أن معامل الثبات للاختبار ككل كما يحددها تطبيق المعادلة على النحو الذى يوضحه جدول (^) : جدول (^) : معامل ثبات (ألفا كرونباخ) لاختبار القياس المصور

\begin{tabular}{|c|c|c|c|c|c|}
\hline معامل ثبات أ & التباين & الاحمراف & المتوسط & العدد العد & الاختبار \\
\hline . ، & 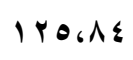 & 11,rr & OrGrr & $r \leq$ & اختبار القياس المصور \\
\hline
\end{tabular}

يتضح من الجدول السابق أن قيمة معامل الثبات للاختبار ككل كما أسفر

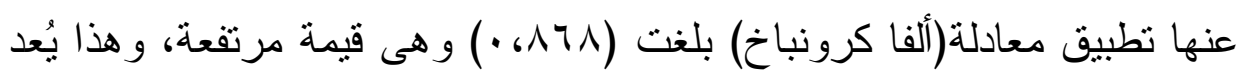
ثبات الاختبار قيد البحث . 
r) تحديد الزمن اللازم لأداء اختبار القياس المصور : تم تحديد الزمن اللازم للإجابة عن الاختبار؛ بتسجيل الزمن الذى استغرقه كل طفل أو طفلة فى مجموعة البحث الاستكثافية لإنهاء الإجابة عن عبار ات الاختبار ثم حساب متوسط مجموع تلك الأزمنة، و أصبح الزمن اللازم لتطبيق اختبار القياس المصور هو (·r) دقيقة، وقد تم الالتز ام بهذا الزمن عند التطبيقين (القبلي و البعدي) لاختبار القياس المصور على مجموعة البحث الأساسية، وبذلك أصبح اختبار القياس المصور فى صورته النهائية صالحاً •للتطبيق على عينة البحث الأساسية

\section{خامسا"" : تطبيق الدر (سة :}

ا ـ تطبيق أدوات البحث قبلياً والتأكد من تكافؤ المجموعتين فى اختبار القياس

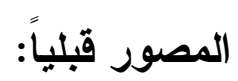

تم استخدام معادلة "ت" لمجموعتين غير مرتبطتين؛ لبحث دلالة الفروق بين متوسطي درجات المجموعتين (التجريبية و الضـابطة) فى اختبار القياس المصور ككل قبلياً، و الجدول ( • () يوضح نلك النتائج:

جدول ( • 1) : قيم "ت" ودلالتها الإحصائية للفروق بين متوسطي درجات المجموعتين (التجريبية والضابطة) في اختبار القياس المصور ككل قبلياً

\begin{tabular}{|c|c|c|c|c|c|c|c|c|}
\hline الالالة & الدلالة & قيم " ت " & الحرية & الالحعراف & المتوسط & العدد & مجموعتي & الاختبار \\
\hline غير دالة & $.601 \mathrm{~V}$ & .6701 & $0 \wedge$ & $r, 0 q$ & •. & $r$. & تجريبية & اختبار القياس \\
\hline & & & & r.q. & $r . .9 r$ & r. & ضابطة & \\
\hline
\end{tabular}

العدد الثانى : أكتوبر •r.r irr 


\section{r. الخطة الزمنية لتطبيق تجربة البحث :}

أــ لتحديد الخطة الزمنية لتدريس البرنامج المقتر ح، و الذى بلغ عدد المفاهيم الفرعية المتضمنة به (r) و عدد الأنشطة (•r) نشاط، (• () أنشطة لكل مفهوم فرعي، وقد تم تدريس تلاك الأنشطة بواقع r أنشطة أسبو عياً، استغرق تدريس كل نشاط (·9) دقيقة، وفى ضوء ذلك اتضحت الخطة الزمنية لتطبيق تجربة البحث وفق الجدول التالى :

\section{جدول(1 1 ) : الخطة الزمنية لتطبيق البحث}

\begin{tabular}{|c|c|c|c|c|}
\hline عدد الأشطة & لكل مفهوم فرعي & الأشطة & عدد & \\
\hline الكلية & استخدام أدوات قياسية & التعرف على بعض أدوات & التقير النسبي للقياسات & المجموعة \\
\hline$r$. & 1. & 1. & 1. & التجريبية \\
\hline
\end{tabular}

عقب الانتهاء من التدريس للمجمو عتين (التجريبية و الضابطة)، تم تطبيق أداة البحث المتمثلة فى اختبار القياس المصور بعدياً على الأطفال عينة البحث، وذلك بهدف تحديد الدرجة الكلية البعدية لأداء الأطفال عينة البحث على الاختبار - المصور

\section{تتائج البحث وتفسيرها :}

* النتائج الخاصة باختبار القياس المصور :

للتحقق من صحة الفرض الأول الذى ينص على : " توجد فروق ذو دلادة إحصائية بين متوسطى درجات أطفال المجموعتين (التجريبية والضابطة) فى التطبيق البعدى لاختبار القياس المصور لصالح المجموعة التجريبية " . 
تم استخدام معادلة " ت" لمجمو عتين غيـر مــرتبطنين؛ لبحــث دلالـــة

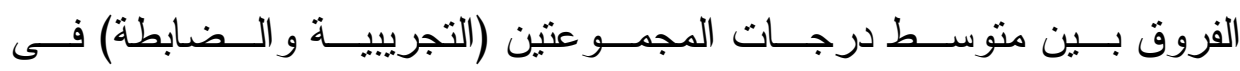

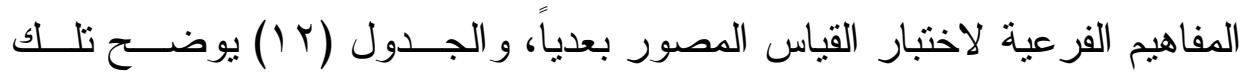

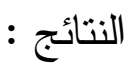

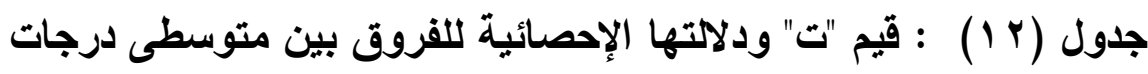
المجموعتين (التجريبية والضابطة) فى اختبار القياس المصور ككل بعدياً

\begin{tabular}{|c|c|c|c|c|c|c|c|}
\hline مستوى الدلالة & " قيم " & الحرية & الاحعر اف & المتوسط & العدد & مجموعتي & للاختبار \\
\hline دالة & $\mid r, r \leqslant 1$ & $0 \wedge$ & 96.1 & $01 ،$. & $r$. & تجريبية & الاختبار ككل \\
\hline & & & r.10 & r.ro & $r$. & ضابطة & \\
\hline
\end{tabular}

يتضح من الجدول السابق وجود فروق ذو دلالة إحصائية بين متوســـي

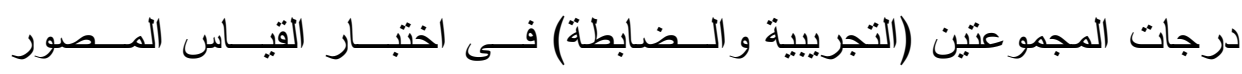
ككل؛ حيث جاءت قيمة " ت" أكبر من القيمة الجدولية حيــث " ت " الجدوليـــة

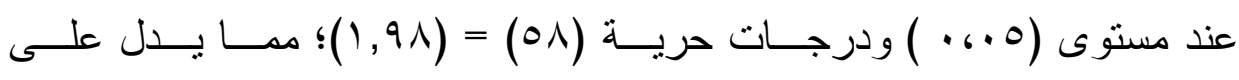
تفوق المجموعة التجريبية على المجموعة الضابطة فى اختبار القياس المـصور ككل .

وفى ضوء تلكـ النتيجة، يمكن قبول الفرض الأول من فـروض البحــث

" توجد فروق ذو دلاية إحصائية عند مستوى دلاكة (0 +، • ) بـين متوســي درجات أطفال المجموعتين (التجريبية والضابطة) في التطبيق البعدي لاختبــار القياس المصور لصالح المجموعة التجريبية "

r.r. العدد الثانى : أكتوبر iro المجلد السابع 
• مقارنة نتائج التطبيق القبلى بالبعدى للمجموعة التجريبية في نتائج اختبار

القياس المصور :

$$
\text { و لاختبار صحة الفرض الثاني الذى بنص على : }
$$

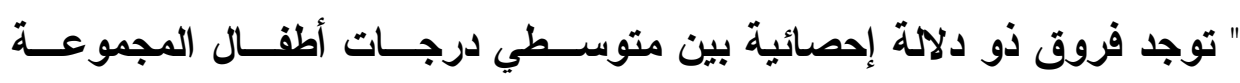

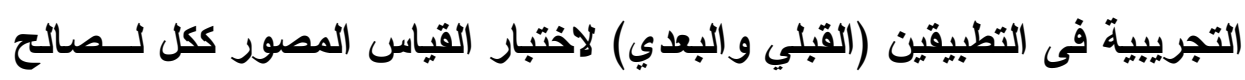

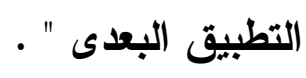

تم استخدام معادلة "ت" للمجموعات المرتبطة لبحث دلالة الفروق بين

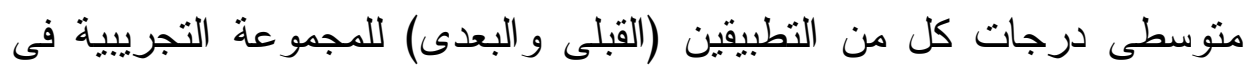
اختبار القياس المصور ككل، و الجدول (r ا () يوضح تلك النتائج : جدول (r ا ) : قيم "ت" ودلالتها الإحصائية للفروق بين متوسطى درجات كل من

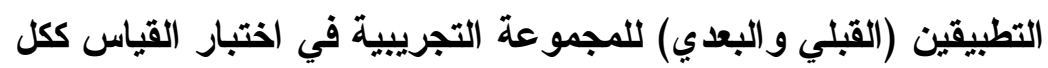

\begin{tabular}{|c|c|c|c|c|c|c|c|}
\hline مستوى & قيم " ت " & الدرجة & المعياري & المتوسط & العدد & | مجموعتي & للاختبار الفرعية \\
\hline دالة & Iroor & rq & $9, .1$ & . \&. & $r$. & تجرييية & الاختبار ككل \\
\hline & & & $r .09$ & r।،؛. & r. & ضابطة & \\
\hline
\end{tabular}

يتضح من الجدول السابق وجود فروق ذو دلالة إحصائية بين منوسطى

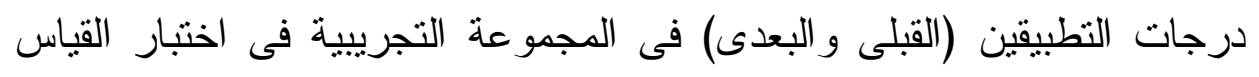

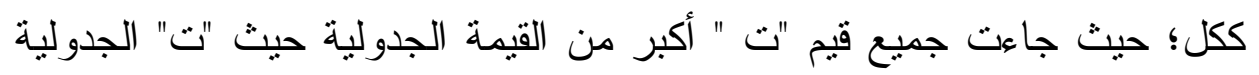

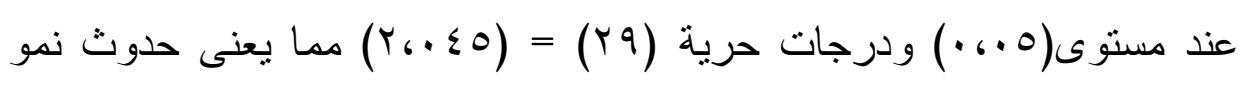

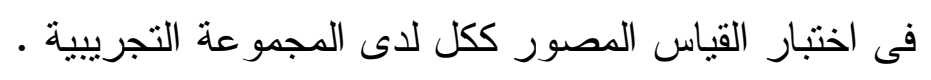


وفى ضوء تلاك النتائج، يمكن قبول الفرض الثانى من فروض البحث وهو : " توجد فروق ذو دلاكة إحصائية عند مستوى (ه .، . ) بين متوسطي درجـات أطفال المجموعة التجريبية في التطبيقين (القبلي والبعدي) لاختبــار القبــاس المصور لصالح التطبيق البعدي" • فاعلية المعالجة التجريبية فى تنمية مفهوم القياس (حجم التأثير) : لتحديد فاعلية المعالجة التجريبية فى تتمية مفهوم القياس، و لاختبار صحة

$$
\text { الفرض الثالث من فروض البحث و هو : }
$$

" يحقق تدريس البرنامج المقترح فاعلية كبيرة باستخدام مربع إيتــا ســوير أعلى من القيمة (؛ (، • ) فى تنمية مفهوم القياس ككل ومفاهيمه الفرعية لاى أطفال مجموعة البحث " أسحة تم استخدام معادلة (ך) لتحديد حجم تأثنير المعالجة فـي تتميــة اختبــار القياس المصور ككل، اعتماداً على قيمة "ت" المحسوبة عند تحديد دلالة الفروق بين التطبيقين (القبلى و البعدى) للمجموعة التجريبية، و الجــدول (ع () يوضــح ذلك :

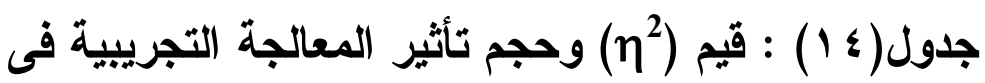
تنمية مفهوم القياس ككل

\begin{tabular}{|c|c|c|c|}
\hline حجم التأثير & $\eta^{2}$ & قيم " ت " & المفاهيم الفرعية للاختبار \\
\hline كبير & . ‘Ar & Ir.Or & الاختبار ككل \\
\hline
\end{tabular}

r.r.r. العلدد الثاذى : أكتوبر 
يتضح من الجدول السابق أن قيم $\eta^{2}$ يعنى أن المعالجة التجريبية تسهم فى التباين الحادث فى اختبار القياس المــصور بنسبة r^\% ، مما بدل على فاعلية المعالجة التجريبية فى تتمية مفهوم القيــاس لدى المجموعة التجريبية .

\section{مناقشة وتفسير النتائج الخاصة باختبار مفهوم القياس المصور:}

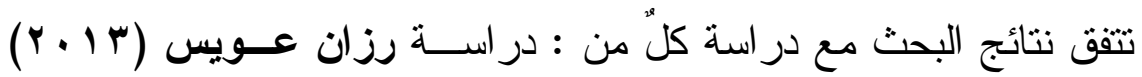

التي استخدمت مدخل اللعب في اكتساب أطفال الروضة مفهوم القيــاس كأحــــ

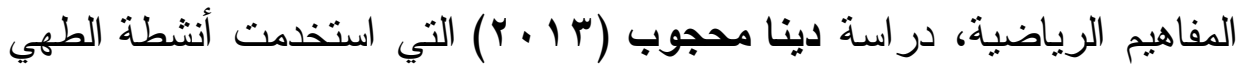
لتتمية بعض المفاهيم العلمية و الرياضية لطفل الروضة، در اسة سهير ابــر اهيم

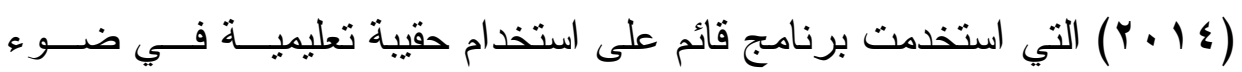
معايير الجودة و أثره على تتمية مفهوم القياس و المهار ات الرياضية والإبداع لدى

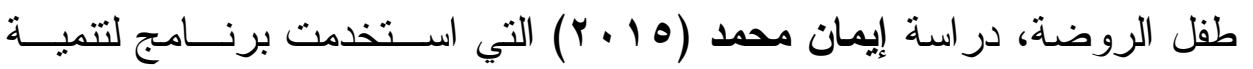
بعض مهار ات القياس (الطول، المسافة، الحجم) لدى طفـلـل الروضــــة، در اســـة رانيا علوان وآخرون (^ ا • r) التي استخدمت الألعاب الإكترونية التعليمية في تتمية مفهوم القياس (كأحد المفاهيم الرياضية) و التقكير الابتكاري لدى طفل مـــا

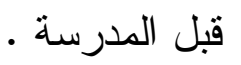

من خلال ما أظهرته النتائج الخاصة باختبار مفهوم القياس المصور لــدى أطفال المجموعة التجريبية برياض الأطفال، يمكن أن نرجع حدوث نمــو فـي بـي مفاهيم القياس الفرعية لديهم إلى:

لا أن تصميم برنامج مُعد خصيصاً لتتمية مفهوم القيــاس ويعتمــد علــى توظيف خبرات الطهي قد أتاح الفرص للأطفال لاكتساب هذا المفهــوم 
بو اسطة الممارسة العملية وهو ما يتفق مع نتائج دراسة ( أمل القــداح

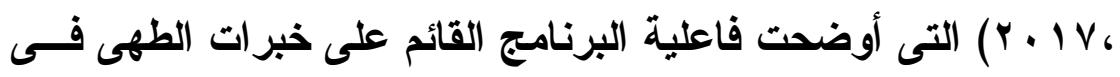

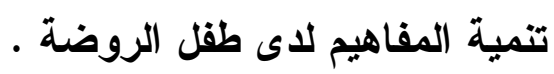

جدوى وفاعلية وتتو ع خبرات الطهي المستخدمة في البرنامج، و التـي

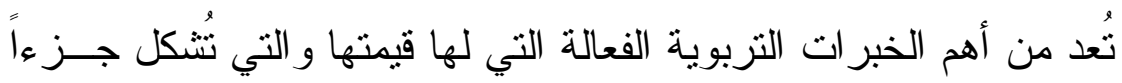

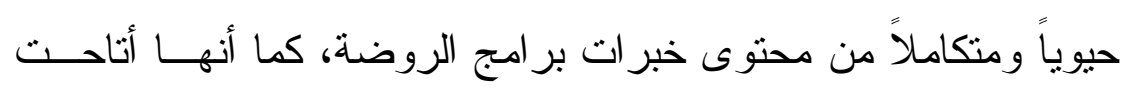

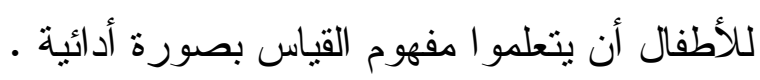

استخدام خبر ات الطهي كأحد مداخل التعلم النشط فــي تـــريب أطفـــال

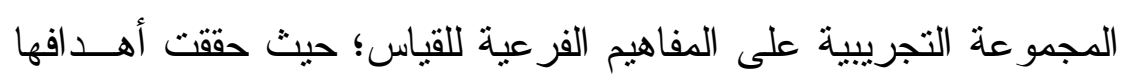

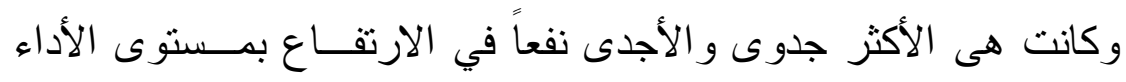

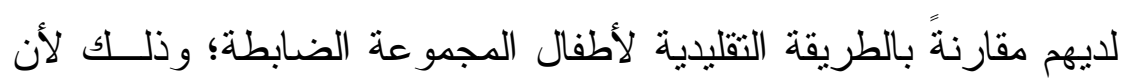

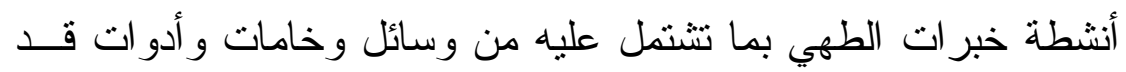

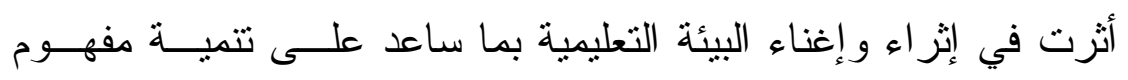

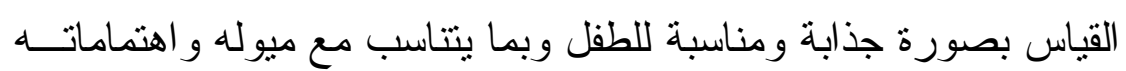
في هذه المرحلة العمرية .

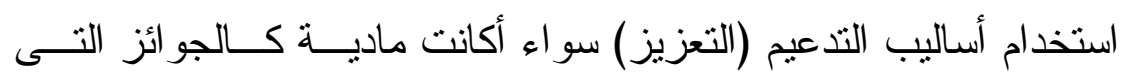

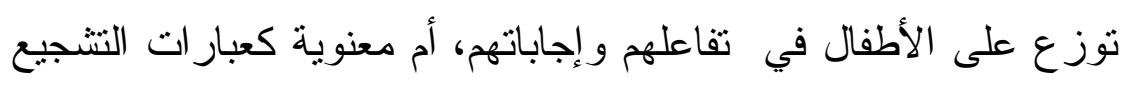
و الاستحسان، التى من شأنها تحفيز الأطفال على التزكيز و الاهتمام أثناء

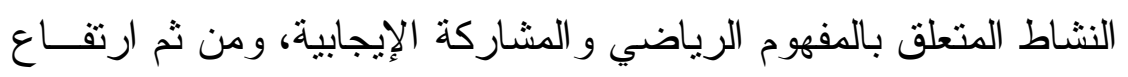
مستوى اكتساب مفهوم القياس لديهم. 
طرح الأسئلة المثيرة للتفكير أثناء كل نشاط على الأطفال، وهذه الأسئلة

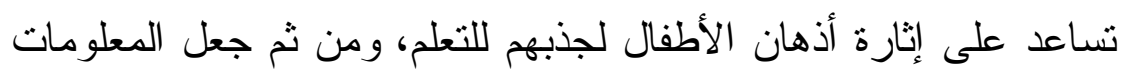

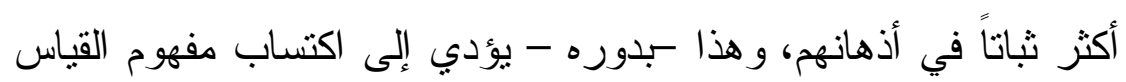
لايهر.

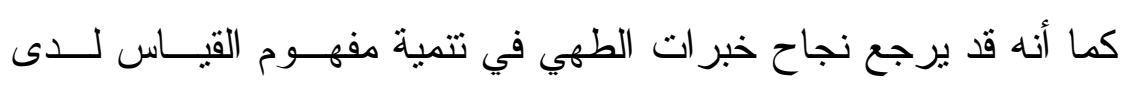

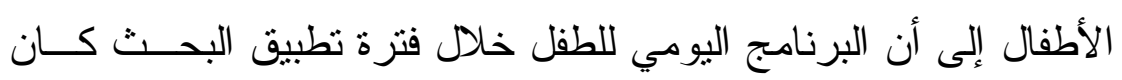
يتضمن أنشطة الطهي التي أسهمت في تتمية مفهوم القياس، وكانت هذه الئه

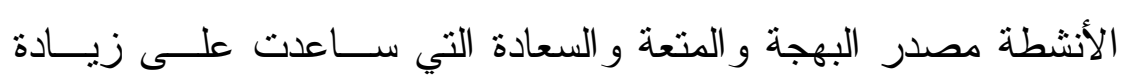
الدافعية في ممارسة الأنشطة وتحقيق الأهداف المرجوة.

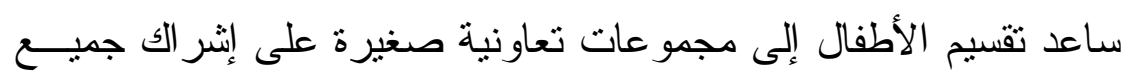

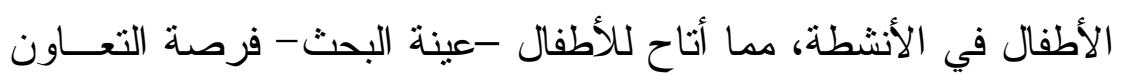

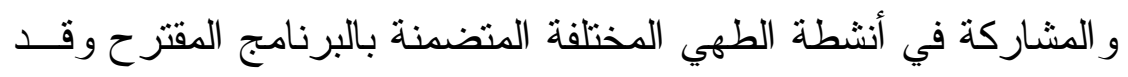
أدى بدوره للتفاعل الإيجابي و المثمر وساهم في الارتفاع بمستوى أدائهم

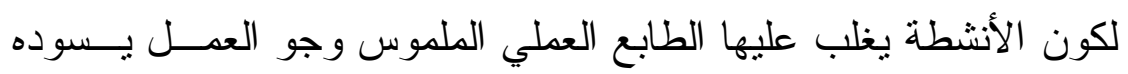

$$
\text { توصيات الدر اسةة : الدرح }
$$

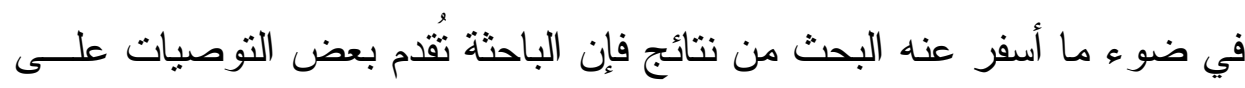

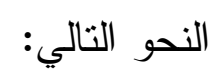

( ) إضافة جزء في دليل معلمة رياض الأطفال يوضح كيفية تتميــة مفهـوم القياس باستخدام أنشطة خبرات الطهي، مع وضع أمثلة ونماذج تطبيقيـــة

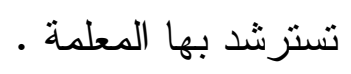

العدد الثانى : أكتوبر ·r.r

$i r$.

المجلد السابع 
r ضرورة تطوير مناهج رياض الأطفال بإضافة محتــوى يتتــاول تتميـــة

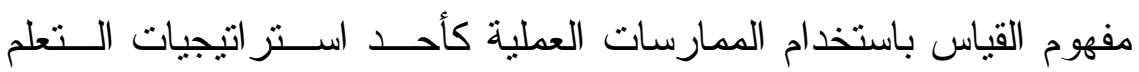

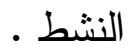

r) إعداد دليل لمعلمة رياض الأطفال يتضمن خبر ات الطهي المناسبة لأطفال الروضة، ويوضح للمعلمة كيفية الاستفادة منها في تتمية مختلف الدفــاهيم

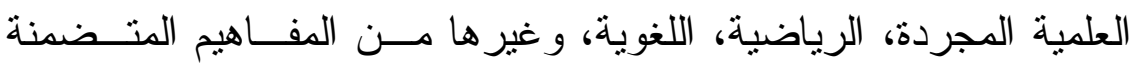
بمجالات التعلم

؛) الاهتمام بعقد دور ات تدرييية لمعلمات رياض الأطفال قبل و أثناء الخدمــة

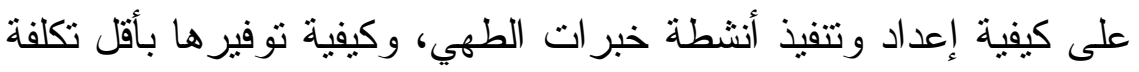

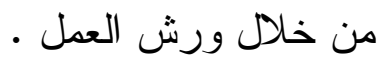
0) إعداد دليل استرشادي للو الدين يوضح الدفاهيم الفرعية لـفهــوم القيــاس وكيفية تتميتها لدى طفل الروضة .

\section{بحوث ودر اسات مقترحة :}

استكمالاً للجهد المُقدم في هذا البحث، لذا يُقتر ح مجموعة مــن الدراســات المستقبلية المرتبطة بمتغير ات البحث الحالي كما يلي:

() استخدام خبر ات الطهي في تتمية المبادرة التفاعلية لطفل الروضـــة فــي ضوء النظرية البنائية الاجتماعية . Y) برنامج مقتر ح لتدريب معلمات رياض الأطفال على اســتخدام خبــرات الطهي لتتمية التفكير العلمي لدى طفل الروضة . 
ب) فعالية برنامج كمبيوتري قائم على خبر ات الطهي لتتمية الوعي الــصحي

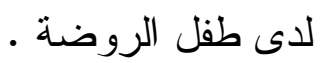

؟) أثز استخدام خبرات الطهي في تتمية بعض المفاهيم الاقتــصادية لــدى طفل الروضة . - مل

0) أثز استخدام استر اتيجية لعب الأدو ار في تتمية المفاهيم الرياضــية لــدى طفل الروضة باستخدام خبر ات الطهي • قائمة المر اجع :

\section{أولاً : المراجع العربية : المراية}

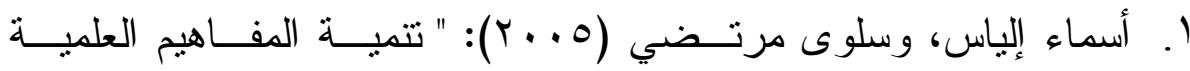

و الرياضية في رياض الأطفال "، مجلة جامعة دمشث، ع(ب)، سوريا.

Y. إقبال منتر، وجاسم نصيف (Y ( • Y): ماهية المفاهيم، وأساليب تصحيح المفاهيم المخطو عة، دار صفاء للنشر و التوزيع، عمان، الأردن.

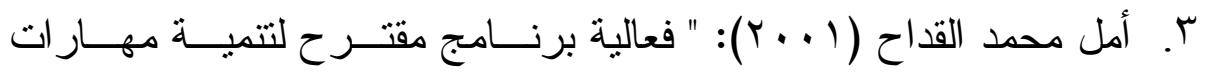

عمليات العلم الأساسية لدى أطفال الروضة "، رســالة دكتــور اه، كليــة التزبية، جامعة المنصورة.

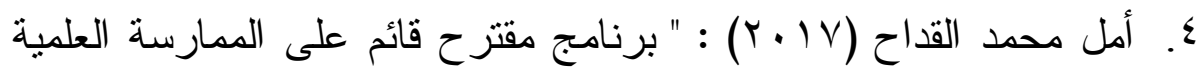

باستخدام خبرات الطهي في تتمية المفاهيم الاجتماعية لدى طفل الروضة في ضوء متغير ات العصر وتحدياته "، المؤتمر الـــدولي الثــاني لكليــة رياض الأطفال، مج(Y)، جامعة المنصورة.

r.r. المجلد السابع




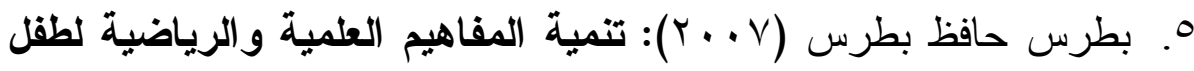
الروضة، دار المسيرة، عمان، الأردن.

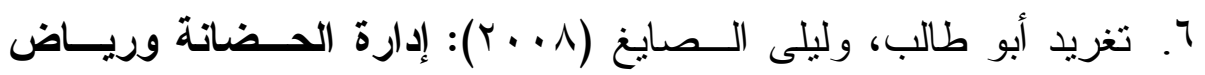

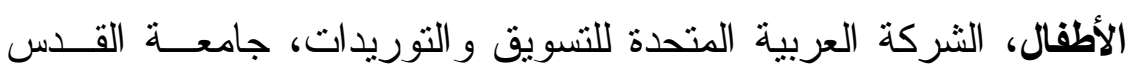
المفتوحة، فلسطين.

V. جوهرة فهذ عبد العزيز الفهيد (Y I ب): " العولمة والثقافة الغذائية لطفل ما قبل المدرسة و علاقتها ببعض المتغيرات السلوكية و المعرفية"، رســالة

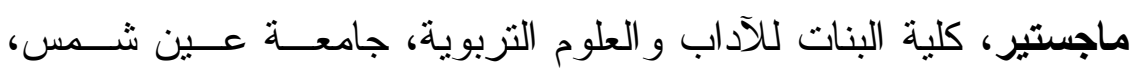
مصر

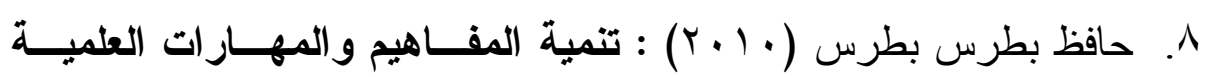

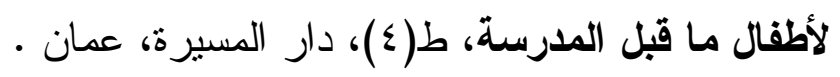

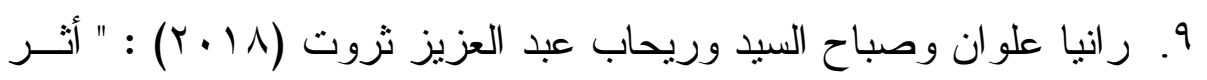

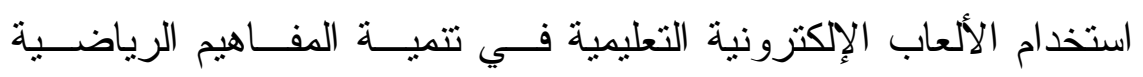

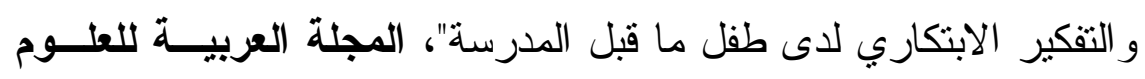

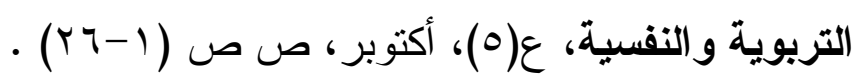

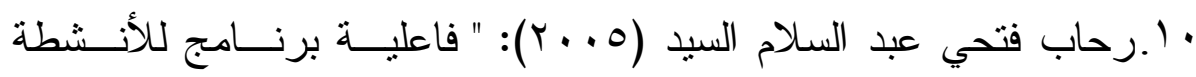

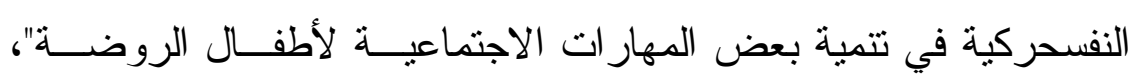
رسالة ماجستير، كلية التربية، جامعة الزقازيق. لئرئ. 


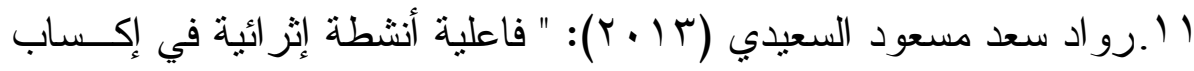
طفل الروضة مفاهيم السلام"، رسالة ماجستير ، كلية التربية، جامعــة أم القرى، المملكة العربية السعودية . r ا.زكريا الثربيني (11 + r): نمو المفاهيم العلمية، دار الفكـر العربـى،

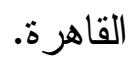

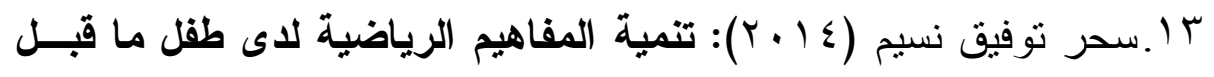
المدرسة، مكتبة الرشد، الرياض.

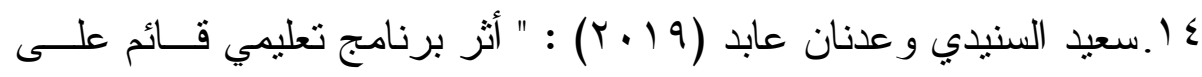
القوة الرياضية في اكتساب المفاهيم الرياضية لدى طلبة الصف الثامن في

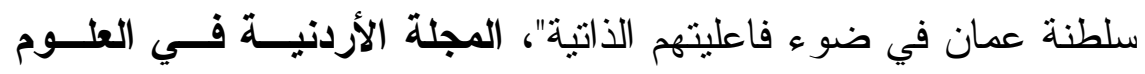

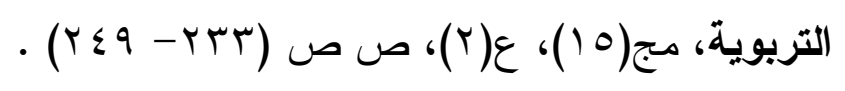

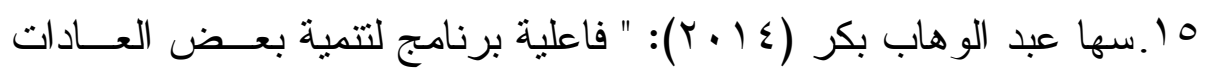

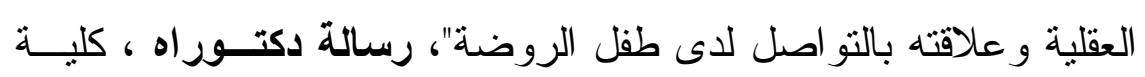
التزبية، جامعة المنصورة.

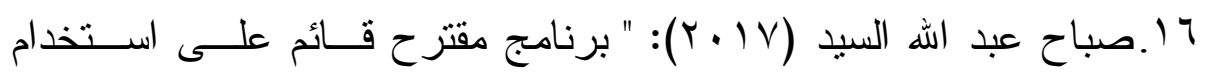

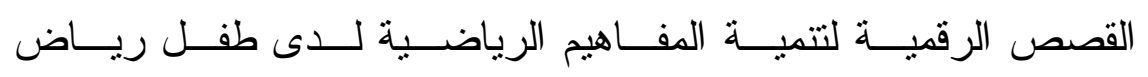

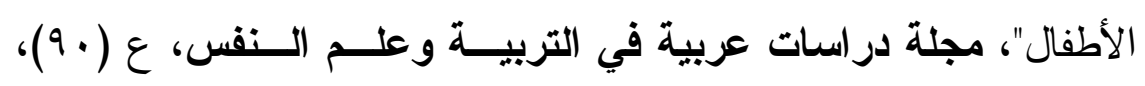
مصر

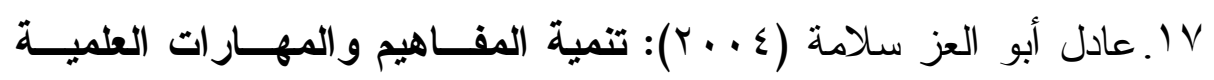
وطرق تدريسها، دار الفكر ، ط (0)، عمان، الأردن. 
1 ا. عزه خليل عبد الفتاح (0. . ب) : الأشطة في رياض الأطفال، دار الفكر العربي، ط (ب)، القاهرة.

9 1. عزة خليل عبد الفتاح (• ( ب): تنمية المفــاهيم العلميــة والرياضــية للأطفال، دار الزهر اء، الرياض، المملكة العربية السعودية.

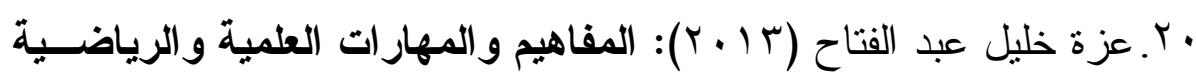
في الطقولة المبكرة للاطفال، دار الفكر العربى، القاهرة.

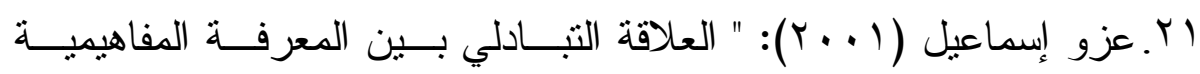

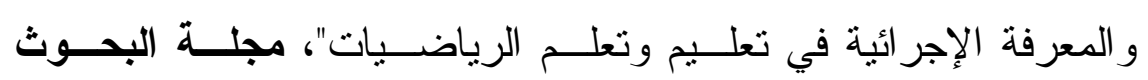
والار اسات التربوية الفلسطينية، ع (0)، فلسطين.

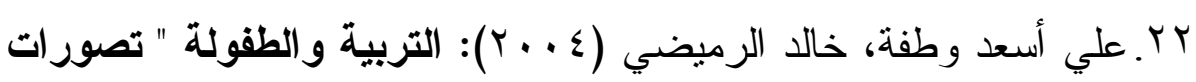
علمية وعقائد نقدية" ، مجد المؤسـسـة الجامعيــة للدر اســات و النــشر

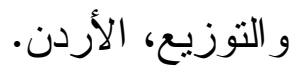

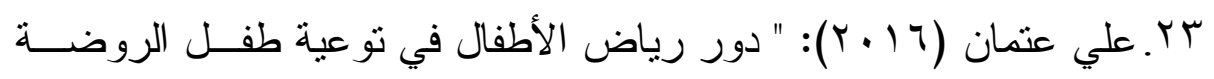

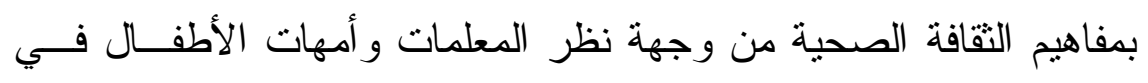

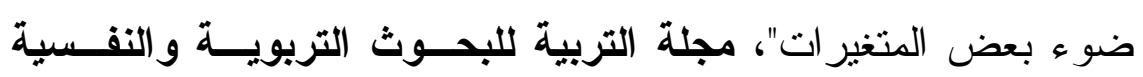
والاجتماعية، عو( 79 (1)، القاهرة.

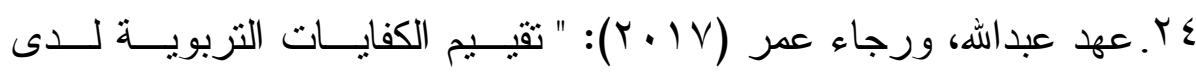
معلمات رياض الأطفال أثثاء فتزة الوجبة لطفل الروضة"، مجلة در اسات

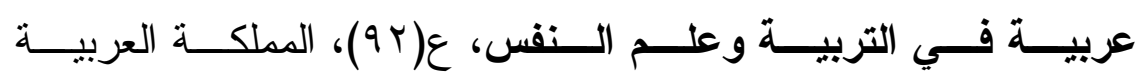
السعودية.

المجلد السابع




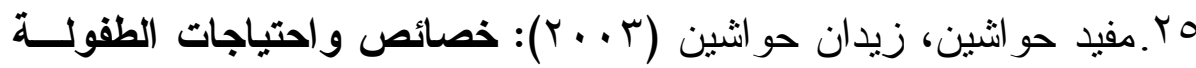
المبكرة، دار الفكر للطباعة و النشر و التوزيع، القاهرة.

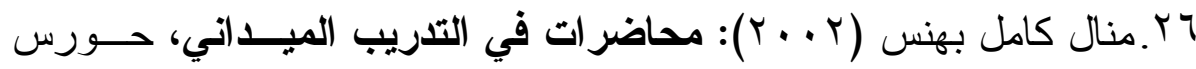
للطباعة و النشر ، القاهرة.

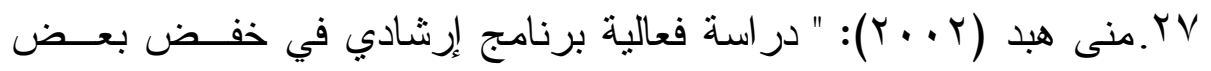

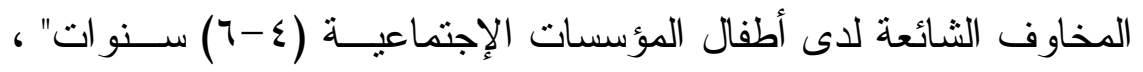
رسالة دكتور اه، معهد الدر اسات العليا للطفولة، جامعة عين شمس.

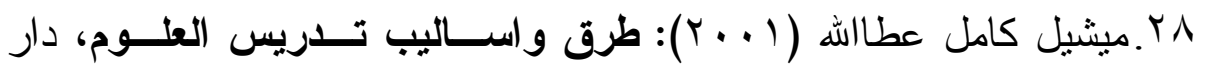
المسيرة للنشر و التوزيع، عمان، الأردن.

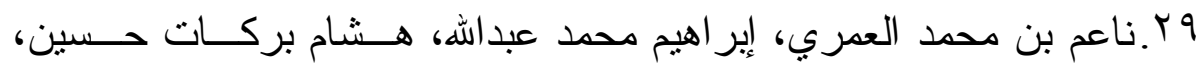

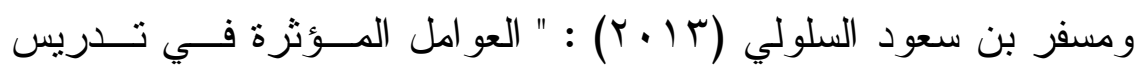

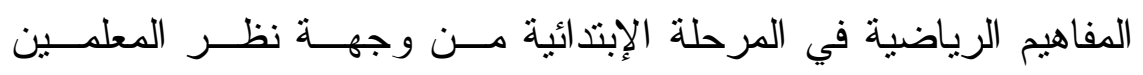
و المشرفين التربوبين"، مجلة العلوم التربوية والنفسية، كليــة التربيـــة،

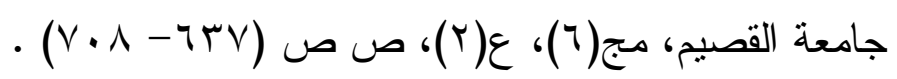

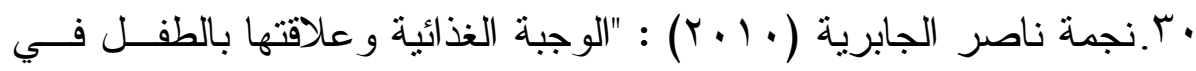
رياض الأطفال"، مجلة التطوير التربــوي، مــج(9)، ع (م)، ســلطنة عمان.

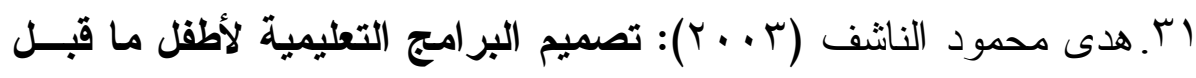
المدرسة، دار الكتاب الحديث، القاهرة. 


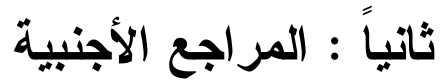

32. Booth, J. L.\& Siegler, R.S.(2008): Numerical magnitude representations influence arithmetic learning, Child Development Journal, Vol.(79), No.(4), PP.(10161031) .

33. Bottini ,Michael , Grossman , Sue.(2005): "The effects of Learning Centers on Young Children Growth and Development ", Childhood Education Journal , Vol.(81), $\mathrm{No}(5)$.

34. Carolyn, E, W.(2011) : Exploring the development of mathematics patterning skills and concepts in young children who experience integrated music and math lessons .

35. Chiappetta, E.L. \& Koballa Jr, T.R. (2010): Science instruction in the middle and secondary schools: Developing fundamental knowledge and skills for teaching. (7th Ed.) Columbus, OH: Pearson.

36. Darbyshire, Jo (2004): Everyday Learning in the kitchen, Early Childhood Australia INC.,Vol.(2),No.(4), WWW.Earlychildhoodaustralia.org.au/on 2/12/2016.

37. Jordan, N.C. \& Levine, S.C. (2009): Socioeconomic variation, number competence, and mathematics learning difficulties in young children, Developmental Disabilities Research Journal, Vol.(15), No(1), PP.(60-68) .

38. Lancour, K. (2004). Process skills for life science: Training guide Retrieved from

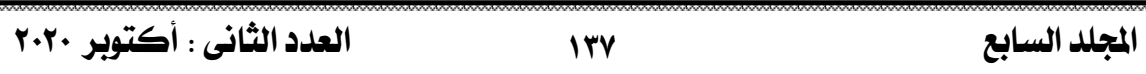


http://www.tufts.edu/as/wright center/products/sci olym piad/pslsl training_hammond.pdf.

39. Loncour, K. (2004). Process skills for life science: Training guide Retrieved from http://www.tufts.edu/as/wright center/products/sci olym piad/pslsl training hammond.pdf.

40. Madson ,Debbie(2013): Kids Cooking Activities, pub.Callisto, united States.

41. Rouadi. N \& Anouti. M. F. (2020) : Teaching Counting in Mathematics in A Digital Learning Environment, a Case Study in a Private School in Beirut, International Journal of Advanced Research in Science, Engineering and Technology, Vol.(7), No.(20), PP. (949- 970). 